Review

\title{
Non-Enzymatic Modification of Aminophospholipids by Carbonyl-Amine Reactions
}

\author{
Alba Naudí, Mariona Jové, Victòria Ayala, Rosanna Cabré, Manuel Portero-Otín and \\ Reinald Pamplona * \\ Department of Experimental Medicine, Faculty of Medicine, University of Lleida-Biomedical \\ Research Institute of Lleida (UdL-IRBLleida), Lleida E25198, Catalonia, Spain; \\ E-Mails: alba.naudi@mex.udl.cat (A.N.); mariona.jove@udl.cat (M.J.); \\ victoria.ayala@mex.udl.cat (V.A.); rosanna.cabre@mex.udl.cat (R.C.); \\ manuel.portero@mex.udl.cat (M.P.-O.)
}

* Author to whom correspondence should be addressed; E-Mail: reinald.pamplona@mex.udl.cat; Tel.: +34-973-702442; Fax: +34-973-702426.

Received: 9 December 2012; in revised form: 21 January 2013 / Accepted: 23 January 2013 / Published: 5 February 2013

\begin{abstract}
Non-enzymatic modification of aminophospholipids by lipid peroxidation-derived aldehydes and reducing sugars through carbonyl-amine reactions are thought to contribute to the age-related deterioration of cellular membranes and to the pathogenesis of diabetic complications. Much evidence demonstrates the modification of aminophospholipids by glycation, glycoxidation and lipoxidation reactions. Therefore, a number of early and advanced Maillard reaction-lipid products have been detected and quantified in different biological membranes. These modifications may be accumulated during aging and diabetes, introducing changes in cell membrane physico-chemical and biological properties.
\end{abstract}

Keywords: advanced glycation endproducts; advanced lipoxidation endproducts; age-associated diseases; aging; cell membrane; carbonyl compounds; lipid peroxidation; Maillard reaction products; oxidative stress; phosphatidylethanolamine; phosphatidylserine 


\section{Introduction}

Life demands membranes. Biological membranes are dynamic structures that generally consist of amphipathic molecules bilayers held together by non-covalent bonds [1,2]. In eukaryotic cells, phospholipids are the predominant membrane lipids and are, from a topographic point of view, asymmetrically distributed across the bilayer [3-5]. Phospholipids consist of a hydrophilic head group with attached hydrophobic acyl chains. The variation in head groups and aliphatic chains allows the existence of more than 1000 different phospholipid species in any eukaryotic cell [6,7]. Phosphatidylcholine (PC), phosphatidylethanolamine (PE), phosphatidylserine (PS), phosphatidylinositol (PI) and cardiolipin (CL), as well as sphingomyelin (SM) and glycosphingolipids (GS) are the major phospholipid classes [1,2]. In most eukaryotic membranes, $\mathrm{PC}$ and PE represent together around $60 \%-85 \%$ of the phospholipid fraction, while the fraction of other phospholipids depends on the cell membrane and even on animal species $[1,2,8,9]$. Phospholipids play multiple roles. They constitute a permeability barrier, modulate the functional properties of membrane-associated activities, provide a matrix for the assembly and function of a wide variety of catalytic processes, and act as donors during the synthesis of macromolecules. The wide range of processes in which phospholipids are specifically involved explains the need for diversity in phospholipid structures and fatty acid composition [6,10]. This diversity requires complex metabolic and regulatory pathways [1,2]. Therefore, for example, eukaryotic cells invest around $5 \%$ of their genes to synthesize all of these lipids [9].

The various phospholipid classes that comprise cell membranes are distributed over both leaflets of the bilayer in a non-random fashion [3-5]. This is especially evident for the aminophospholipids, PS and PE, which preferentially reside in the plasma membranes' inner leaflet [11,12]. Where does lipid asymmetry originate, and how is it maintained and regulated? What is the functional role of aminophospholipid asymmetry, and what are the consequences of the breakdown of regulatory processes that result in the exposure of aminophospholipids in the cells' outer leaflet? Although these key questions mainly remain unanswered, recent studies have established that cells have developed a number of mechanisms to deal with this issue. Targeting phospholipids to specific membrane sites is essential for maintaining critical signal transduction cascades, cell shape, hemostasis, and homeostasis [12]. In particular, aminophospholipids have been implicated in a diverse array of processes ranging from cell proliferation to cell death, from catabolism to inflammation [12]. In this scenario, asymmetry is maintained by active ATP-dependent processes, suggesting that is critical to normal cell function. Specifically, aminophospholipid asymmetry is controlled by one or more specific mechanisms, which involve selective interactions between lipids and cytoskeletal proteins and an aminophospholipid-specific active transport system [11,12].

The acyl chains are composed of either saturated, monounsaturated or polyunsaturated hydrocarbon chains that normally vary from 14 to 22 carbons in length [13]. In eukaryotic cells from vertebrate species, the average chain length of a biological membrane is strictly maintained by around 18 carbon atoms, and the relative distribution between saturated and unsaturated fatty acids follows the ratio 40:60 [14]. Polyunsaturated fatty acids (PUFAs) are essential components of cellular membranes in higher eukaryotes that strongly affect their fluidity, flexibility and selective permeability. Additionally, PUFAs affect many cellular and physiological processes in animals, including modulation of ion 
channels and carriers, activities of membrane-associated enzymes, and regulation of gene expression, among others [13].

Thus, membrane composition (phospholipids classes' distribution and fatty acid profile) is strictly and dynamically regulated. The mechanisms of the homeostatic regulation of the membrane composition, the mechanisms that create lipid asymmetry and their functional implications, and the full definition of the utility of the eukaryotic lipid repertoire are beginning to be understood, being an exciting and rapidly expanding field.

\section{Membrane Unsaturation and Lipid Peroxidation}

As a principle, chemical reactions in living cells are under strict enzyme control and are tightly regulated by the metabolic program. One of the attractors involved in biomolecular evolution is the minimizing of unnecessary side reactions. Nevertheless, uncontrolled and potentially deleterious reactions occur, even under physiological conditions. Oxidative damage is a broad term used to cover the attack upon biological molecules by free radicals - chemical species with one unpaired electron. Free radicals attack/damage all cellular constituents [14]. In this context, the susceptibility of membrane phospholipids to oxidative damage is related to two inherent traits, the physico-chemical properties of the membrane bilayer and the chemical reactivity of the fatty acids composing the membrane [15]. The first property is related to the fact that oxygen and free radicals are more soluble in the fluid lipid bilayer than in the aqueous solution. Thus, membranes contain an interior organic phase, in which oxygen may tend to concentrate. Therefore, these differences in solubility are important when considering the availability of oxygen/free radicals for chemical reactions inside living systems: Organic regions may contain more free radicals than aqueous regions [16,17] and, consequently, membrane lipids become primary targets of oxidative damage. The second property is related to the fact that PUFA residues of phospholipids are extremely sensitive to oxidation. Every membrane phospholipid contains an unsaturated fatty acid residue esterified to the 2-hydroxyl group of its glycerol moiety. Many of these are polyunsaturated and the presence of a methylene group between two double bonds renders the fatty acid sensitive to free radical-induced damage, their sensitivity to oxidation increasing exponentially as a function of the number of double bonds per fatty acid molecule [18,19]. Consequently, the high concentration of PUFAs in phospholipids not only makes them prime targets for reaction with oxidizing agents but also enables them to participate in long free radical chain reactions.

Lipid peroxidation generates hydroperoxides as well as endoperoxides, which undergo fragmentation to produce a broad range of reactive intermediates called reactive carbonyl species (RCS) with three to nine carbons in length (see Figure 1), the most reactive being $\alpha, \beta$-unsaturated aldehydes (4-hydroxy-trans-2-nonenal (HNE) and acrolein), di-aldehydes (malondialdehyde (MDA) and glyoxal), and keto-aldehydes (4-oxo-trans-2-nonenal (ONE) and isoketals) [20,21]. 2-Hydroxyheptanal (2-HH) is another major aldehydic product of lipid peroxidation of PUFAn-6, while 4-hydroxyhexenal (4-HHE) is generated in a lower yield. Additionally, a number of other short chain aldehydes are produced during lipid peroxidation through poorly understood mechanisms. These carbonyl compounds, ubiquitously generated in biological systems, have unique properties contrasted with free radicals [14]. For instance, compared with free radicals, reactive aldehydes have a much 
longer half-life (i.e., minutes to hours instead of microseconds to nanoseconds for most free radicals). Further, the non-charged structure of aldehydes allows them to migrate with relative ease through hydrophobic membranes and hydrophilic cytosolic media, thereby extending the migration distance far from the production site. Based on these features alone, these carbonyl compounds can be more destructive than free radicals and may have far-reaching damaging effects on target sites within or outside membranes.

Therefore, the highly unsaturated fatty acids present in cellular membranes are the most susceptible macromolecules to oxidative damage in cells, and this sensitivity increases as a function of their number of double bonds. In addition, the carbonyl compounds generated as lipid peroxidation-derived end products extend the membrane damage to other cellular constituents.

Figure 1. General structures of principal reactive carbonyl species detected in biological systems.

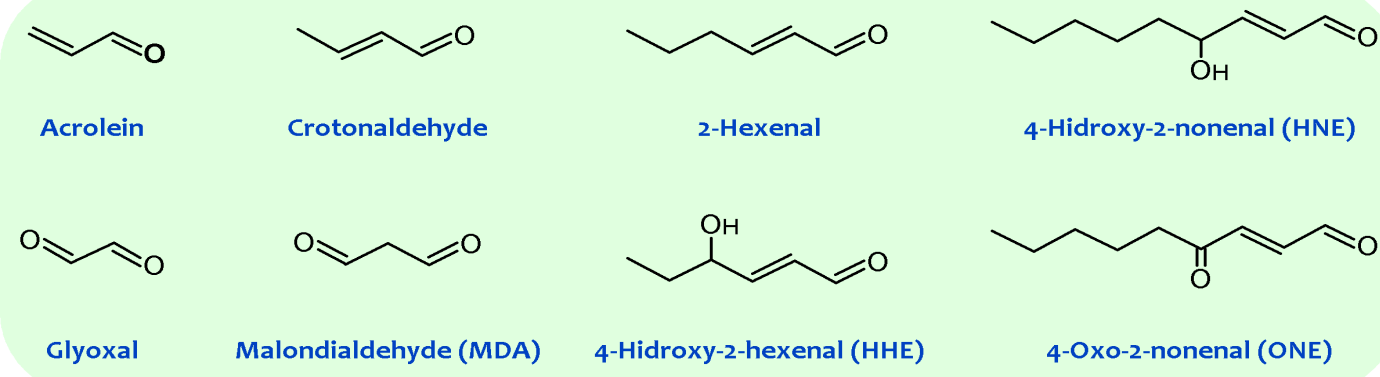

\section{Non-Enzymatic Modification of Cellular Components: The Maillard Reaction-Derived Molecular Damage}

Carbonyl compounds react with nucleophilic groups in macromolecules like proteins and DNA, resulting in their chemical, non-enzymatic, and irreversible modification and finally in the formation of a variety of adducts and cross-links collectively named Advanced Lipoxidation Endproducts (ALEs) [22,23]. Thus, by reacting with nucleophilic sites in proteins (belonging basically to Cys, Lys, Arg, and His residues), carbonyl compounds generate ALE adducts such as MDA-Lys, HNE-Lys, FDP-Lys, and S-carboxymethyl-cysteine; and the cross-links glyoxal-lysine dimmer, and lysine-MDA-lysine, among several others. The accumulation of MDA adducts on proteins is also involved in the formation of lipofuscin. Thus, lipofuscin becomes a nondegradable intralysosomal fluorescent pigment formed through lipoxidative reactions [24]. In addition to proteins, lipid peroxidation-derived endproducts can also react with the exocyclic amino groups of deoxyguanosine, deoxyadenosine, and deoxycytosine to form various alkylated products [25]. Guanine is, however, the most commonly modified DNA base because of its high nucleophilicity. Some common enals that cause DNA damage, analogously to proteins, are MDA, HNE, and acrolein, among others. Thus, the most common adducts arising from enals are exocyclic adducts such as etheno adducts, and MDA-deoxyguanosine (M1dG).

In addition to lipid peroxidation derived carbonyl compounds, reducing sugars and carbonyl compounds derived from carbohydrate oxidation can also react with the primary amino groups of macromolecules such as proteins and DNA, following the principles of the carbonyl-amine reaction (also named Maillard reaction) [22]. The early Schiff base and Amadori adducts (glycation reaction), 
which form subsequently, slowly undergo a succession of intramolecular rearrangements, dehydration, and oxidation-reduction reactions to produce the terminal products termed advanced glycation end products (AGEs), which are often chemically irreversible, thus persisting throughout the life of the affected macromolecule [26,27]. More important, a major spin-off of studies on glycation during the 1980s was the recognition that oxidative reactions, and by inference, oxidative stress, catalyzed the chemical modification of proteins and DNA by Maillard reactions in vivo [28].

In this scenario, it is likely that the amino group of aminophospholipids will also react with carbonyl compounds and initiates some of the reactions occurring in proteins and DNA, expanding the biological effects of the carbonyl-amine or Maillard reaction (see Figure 2).

Figure 2. Protein, DNA and aminophospholipid damage resulting from carbonyl products of lipid peroxidation. Shown are examples of molecular adducts (Advanced Lipoxidation Endproducts, ALEs) generated by the reactive carbonyl compound glyoxal.
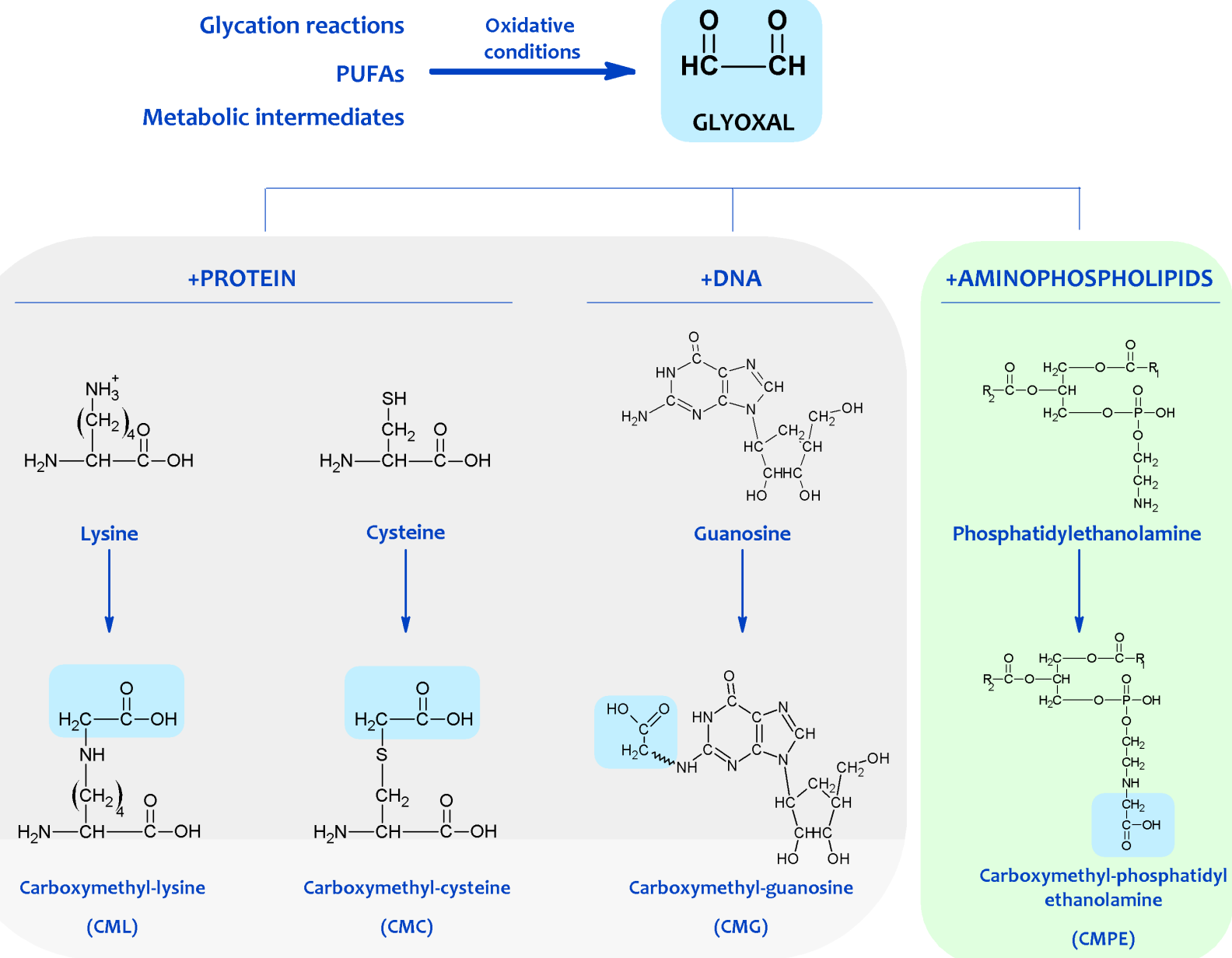

Hence, Maillard reaction-derived molecular damage is a natural consequence of aerobic life. Maillard reaction products (MRPs, including AGEs and ALEs) induce the chemical, non-enzymatic and irreversible modification of cellular constituents, and they are part of the evidence for the existence of an "oxidative stress" in vivo. Little is known about molecular modification by MRPs, particularly regarding aminophospholipids. A current challenge is to establish the chemical structure of these modifications and the mechanisms for their formation, and to identify which factors control the 
nature, selectivity, extent, irreversibility and biological-pathological consequences of the molecular modification occurring in vivo.

\section{Chemical Modification of Aminophospholipids by Carbonyl-Amine Reactions}

Recent reports indicate that, like proteins and DNA, aminophospholipids are also targets of Maillard-type reactions. In early studies, the formation of products resulting from the reaction between aminophospholipids and lipoperoxidation-derived aldehydes such as MDA and HNE were described, but the exact structure of the products was not established. In these works, it was established that the amount of free amino groups significantly decreased during oxidation of phospholipids, developing a brownish-yellow color attributed to a Maillard-type reaction [29]. It was also reported that free amino groups of PE disappeared during oxidation in proportion to the oxygen absorbed [30]. Probably, both findings can be attributed to the reaction of the PE amino group with carbonyls, mainly MDA produced by lipid oxidation, leading to Schiff base formation as assessed by fluorescence. So, during peroxidation, PE and PS formed fluorescent chromophores with maximum emission ranging from 440 to $490 \mathrm{~nm}$ and maximum excitation between 360 and $400 \mathrm{~nm}$ [31,32]. Fluorescence development was related to (i) formation of thiobarbituric acid reactive substances (TBARS), especially MDA; (ii) reaction time; (iii) availability of reactive amino groups on the aminophospholipids, and (iv) antioxidant (alpha-tocopherol) content in an inverse fashion. These chromophores showed similarities to those formed in model membranes [33] or in rat liver mitochondrial and microsomal fractions peroxidized in vitro [31,32]. Furthermore, lipid extracts isolated from lipofuscin [34] and from tissues of lipid peroxidation-experimental models such as old, vitamin E deficient animals or animals stressed with highly unsaturated lipid diets, showed similar fluorescence properties [31,32]. Table 1 offers, chronologically, a summary of studies dedicated to the characterization of Maillard reaction-derived compounds on aminophospholipids.

Using thin-layer chromatography (TLC), non-enzymatic modification of aminophospholipids by lipoperoxidation derived products were also detected in red blood cells (RBC) [35-42] and in eye lens membranes [43,44]. These modifications corresponded to a Schiff's base adduct formed by cross-linking the PE and PS amino with MDA aldehyde groups, based on the following evidence: (i) A new lipid spot appeared between PS and PE; (ii) its intensity was proportional to MDA concentration both in vivo and in vitro; (iii) in selective staining procedures, it was phosphorus positive and ninhydrin negative; (iv) when this compound was exposed to acid vapors and then developed in a second direction, the "adduct" was resolved into two equimolar spots of PS and PE which were ninhydrin positive; (v) other non-amino phospholipids were ineffective in the formation of this compound; (vi) its fluorescence characteristics were compatible with a Schiff base conjugate formed between MDA and aminophospholipids; and finally, (vii) added antioxidants, blocking MDA formation, avoided its appearance.

Lipid peroxidation leads to the formation of other aldehydes, such as HNE, able to react with aminophospholipids. Accordingly, the formation of fluorescent chromolipids was detected when HNE was incubated with aminophospholipids, microsomes and mitochondrial fractions [45,46]. Spectral characteristics of these chromolipids showed excitation maxima at 350-360 nm and emission at $430 \mathrm{~nm}$, with the fluorescence intensity being linearly related to the number of HNE molecules 
reacting with aminophospholipids [45]. More recently, HNE potential capacity to react with aminophospholipids has been reported. Thus, by using TLC-high performance liquid chromatography (HPLC)-liquid chromatography (LC)-mass spectrometry (MS) techniques, it has been found that the main resulting compounds were a Michael adduct plus a minor Schiff base adduct, partly cyclized as a pyrrole derivative via a loss of water, with PE being more reactive than PS [46].

Table 1. Summary of studies addressing the characterization of non-enzymatic aminophospholipid modification by carbonyl-amine reactions.

\begin{tabular}{|c|c|c|c|}
\hline Experimental model & Analytical approach & Structural characterization & Ref. \\
\hline \multicolumn{4}{|c|}{ In vitro Studies } \\
\hline $\begin{array}{c}\text { Peroxidation of arachidonate and } \\
\text { docosahexaenoate }+ \text { synthetic dipalmitoyl } \\
\text { phosphatidylethanolamine }\end{array}$ & Fluorimeter & $\begin{array}{l}\text { Fluorescence chromophores } \\
\text { (Ex } 360 \mathrm{~nm}, \mathrm{Em} 430 \mathrm{~nm})\end{array}$ & {$[31]$} \\
\hline $\begin{array}{l}\text { Rat liver mitochondrial and microsomal } \\
\text { fractions peroxidized in vitro }\end{array}$ & Fluorimeter & $\begin{array}{l}\text { Fluorescent chromophores } \\
(\text { Ex } 365-370 \mathrm{~nm}, \text { Em } 435-440 \mathrm{~nm})\end{array}$ & {$[47]$} \\
\hline $\begin{array}{c}\text { Methyl arachidonate/ methyl linolenate/ } \\
\text { methyl linoleate/ Malondialdehyde }+ \\
\text { phosphatidylethanolamine/ } \\
\text { phosphatidylserine (PE/ PS) }\end{array}$ & Fluorimeter & $\begin{array}{l}\text { Fluorescent chromophores } \\
\text { (Ex } 365 \mathrm{~nm}, \text { Em } 435 \mathrm{~nm})\end{array}$ & {$[32]$} \\
\hline Malondialdehyde + Red blood Cells (RBC) & Fluorimeter & $\begin{array}{l}\text { Fluorescent chromophores } \\
\text { (Ex 390-400 nm, Em } 460 \mathrm{~nm})\end{array}$ & {$[35]$} \\
\hline Lipid peroxidation of rat liver microsomes & Fluorimeter & $\begin{array}{l}\text { Fluorescent chromophores } \\
(\text { Ex } 359 \mathrm{~nm}, \text { Em } 430 \mathrm{~nm})\end{array}$ & [48] \\
\hline Lipid peroxidation-derived compounds & Fluorimeter & $\begin{array}{l}\text { Fluorescent chromophores } \\
(\text { Ex } 360 \mathrm{~nm}, \text { Em } 435 \mathrm{~nm})\end{array}$ & [33] \\
\hline Malondialdehyde + primary amines & Fluorimeter & $\begin{array}{l}\text { Identification of 1-4-Dihydropyridine- } \\
\text { 3,5-Dicarbaldehydes as model of } \\
\text { fluorescent components in lipofuscin } \\
\text { (Ex } 375-405 \mathrm{~nm}, \mathrm{Em} 435-465 \mathrm{~nm})\end{array}$ & [49] \\
\hline $\begin{array}{l}\text { 4-Hydroxynonenal (4-HNE) }+ \\
\text { microsomes/mictochondria/phospholipids } \\
\text { (PS and PE) }\end{array}$ & Fluorimeter & $\begin{array}{l}\text { Fluorescent chromophores } \\
(\text { Ex } 360 \mathrm{~nm}, \text { Em } 430 \mathrm{~nm})\end{array}$ & {$[45]$} \\
\hline Malondialdehyde $(\mathrm{MDA})+$ serine & $\begin{array}{l}\text { Nuclear magnetic } \\
\text { resonance (NMR) } \\
\text { and (high } \\
\text { performance liquid } \\
\text { chromatography } \\
\text { (HPLC) }\end{array}$ & $N$-2-(Propenal)serine & {$[50]$} \\
\hline MDA + ethanolamine & NMR and HPLC & $N$-(2-propenal)ethanolamine & [51] \\
\hline $\begin{array}{l}\text { Mixed liposomes of L-alpha-dilinoleoyl- } \\
\text { phosphatidylcholine (DiLinPC) and } \\
\text { L-alpha- } \\
\text { Dilinoleoylphosphatidylethanolamine } \\
\text { (DiLinPE) in oxidative conditions }\end{array}$ & $\begin{array}{c}\text { Fluorimeter and } \\
\text { oxygen consumption } \\
\text { monitored } \\
\text { polarographically } \\
\text { with a Clark-type } \\
\text { oxygen probe }\end{array}$ & $\begin{array}{l}\text { Fluorescent chromophores } \\
(\text { Exc } 360 \mathrm{~nm}, \text { Em } 430 \mathrm{~nm})\end{array}$ & {$[52]$} \\
\hline
\end{tabular}


Table 1. Cont.

\begin{tabular}{|c|c|c|c|}
\hline Experimental model & Analytical approach & Structural characterization & Ref. \\
\hline \multicolumn{4}{|c|}{ In vitro Studies } \\
\hline Glucose $+\mathrm{PE}$ and PS & $\begin{array}{c}\text { Liquid } \\
\text { chromatography- } \\
\text { electrospray } \\
\text { ionization-mass } \\
\text { spectrometry (LC- } \\
\text { ESI-MS and TLC) }\end{array}$ & Glycated aminoglycerophospholipids & {$[53]$} \\
\hline Lens + oxidative conditions & Fluorimeter and TLC & $\begin{array}{l}\text { MDA:aminophospholipid adducts } \\
(\text { Ex } 360 \mathrm{~nm}, \text { Em } 470 \mathrm{~nm})\end{array}$ & [44] \\
\hline $\begin{array}{l}\text { Glycoxidation and autoxidation of PE from } \\
\qquad \text { RBCs }\end{array}$ & $\begin{array}{l}\text { Gas chromatography- } \\
\text { mass spectrometry } \\
(\mathrm{GC}-\mathrm{MS})\end{array}$ & $\begin{array}{c}\text { Carboxymethyl-ethanolamine } \\
\text { (as marker of carboxymethyl- } \\
\text { phosphatidylethanolamine, CM-PE) }\end{array}$ & {$[54]$} \\
\hline Glucose + phosphatidylethanolamine & $\begin{array}{c}\text { Gas-liquid } \\
\text { chromatography- } \\
\text { mass spectrometry } \\
\text { (GLC-MS) and } \\
\text { HPLC with diode- } \\
\text { array detection } \\
\text { (DAD) }\end{array}$ & $\begin{array}{l}\text { 1-deoxy-1-(2-hydroxyethylamino)- } D \text { - } \\
\text { fructose derivatives }\end{array}$ & {$[55]$} \\
\hline $\begin{array}{c}\text { Glucose }+ \text { PE/phosphatidylcholine (PC)-PE } \\
\text { liposomes }\end{array}$ & $\begin{array}{c}\text { Thin layer } \\
\text { chromatography } \\
\text { (TLC), HPLC, NMR, } \\
\text { fast atomic } \\
\text { bombardment } \\
\text { (FAB)-MS }\end{array}$ & Deoxy- $D$-fructosyl PE & {$[56]$} \\
\hline $\begin{array}{l}\text { (2-aminoethyl)phenetydylphosphate and (2- } \\
\text { aminoethyl)ethylphosphate as model of } \\
\text { aminophospholipids + carbohydrates }\end{array}$ & HPLC, NMR & Aminophospholipid glycation & {$[57]$} \\
\hline $\mathrm{PE}$ and $\mathrm{PS}+$ glucose & GC-MS & $\begin{array}{l}N \text {-(glucitol)ethanolamine and } \\
N \text {-(carboxymethyl)serine }\end{array}$ & {$[58]$} \\
\hline $\begin{array}{l}\text { Human low density lipoprotein }(\mathrm{hLDL})+\mathrm{p} \text { - } \\
\text { hydroxyphenylacetaldehyde } \\
\text { (p-hydroxyphenylacetaldehyde (pHA), } \\
\text { product of L-tyrosine oxidation by the } \\
\text { myeloperoxidase system of macrophages) }\end{array}$ & GC-MS & pHA-ethanolamine & [59] \\
\hline Glucose and 3-Deoxyglucosone $+\mathrm{PE}$ & $\begin{array}{l}\text { GLC-MS and } \\
\text { HPLC-DAD }\end{array}$ & $\begin{array}{c}\text { Formation of a phospholipid-linked } \\
\text { pyrrolecarbaldehyde }\end{array}$ & [60] \\
\hline Carbohydrates $+\mathrm{PE}$ & $\begin{array}{l}\text { LC-ESI-MS, } \\
\text { HPLC-DAD, and } \\
\text { NMR }\end{array}$ & PE-derived Amadori compounds & [61] \\
\hline $\begin{array}{c}\mathrm{PE}+4,5(\mathrm{E}) \text {-epoxy-2(E)-heptenal } \\
\text { (secondary product of lipid peroxidation) }\end{array}$ & $\begin{array}{l}\text { GC-MS, HPLC-MS, } \\
\text { NMR }\end{array}$ & $\begin{array}{c}\text { Phosphatidylethanolpyrroles and } \\
\text { phosphatidylethanol-2-(1- } \\
\text { hydroxypropyl)pyrroles }\end{array}$ & [62] \\
\hline
\end{tabular}


Table 1. Cont.

\begin{tabular}{|c|c|c|c|}
\hline Experimental model & Analytical approach & Structural characterization & Ref. \\
\hline \multicolumn{4}{|c|}{ In vitro Studies } \\
\hline $\begin{array}{c}\mathrm{PE}+13 \text {-hydroperoxyoctadecadienoic acid } \\
\text { and other oxidized poly unsaturated fatty } \\
\text { acids (PUFAs) followed by phospholipase } \\
D \text {-mediated hydrolysis }\end{array}$ & LC-MS and NMR & $N$-(hexanoyl)ethanolamine & [63] \\
\hline $\begin{array}{l}\text { Different species of PE + 4-hydroxy-trans- } \\
\text { 2-nonenal (4-HNE)/ } \\
\text { 4-hydroxydodecadienal (4-HDDE)/ } \\
\text { 4-hydroxyhexenal (4-HHE) }\end{array}$ & $\begin{array}{l}\text { GC-MS, TLC, } \\
\text { HPLC, and NMR }\end{array}$ & $\begin{array}{c}\text { Aldehydes-PE. } \\
\text { Different PE species are differently } \\
\text { targeted by fatty aldehydes }\end{array}$ & [64] \\
\hline PE + Isoketals (IsoK) & LC-ESI-MS & $\begin{array}{l}\text { IsoK-PE pyrrole adducts and } \\
\text { IsoK-PE Schiff base adducts }\end{array}$ & {$[65]$} \\
\hline $\begin{array}{c}\text { Fatty aldehydes released from plasmalogens } \\
\text { after oxidation of cerebral cortex } \\
\text { homogenates }\end{array}$ & GC-MS & $N$-heptadecyl-PE & [66] \\
\hline $\begin{array}{l}\text { PE + Glucose + Potential "antiglycative" } \\
\text { compounds (protein glycation inhibitors, } \\
\text { antioxidants, vitamins, etc.) }\end{array}$ & LC-ELSD-MS & $\begin{array}{c}\text { Amadori-PE. } \\
\text { Pyridoxal 5'-phosphate and } \\
\text { pyridoxal/vitamin B6 derivatives) are } \\
\text { the most effective antiglycative } \\
\text { compounds }\end{array}$ & {$[67,68]$} \\
\hline Acetoacetate + brain aminophospholipids & $\begin{array}{c}\text { TLC and } \\
\text { spectrophotometry }\end{array}$ & UV spectroscopy at $280 \mathrm{~nm}$ & [69] \\
\hline Acetaldehyde-PE & $\begin{array}{c}\text { Density functional } \\
\text { theory study }\end{array}$ & $\begin{array}{l}\text { Schiff base formation between PE and } \\
\text { acetaldehyde }\end{array}$ & [70] \\
\hline $\begin{array}{l}\text { Liposomes and human high density } \\
\text { lipoprotein (hHDL) particles in oxidative } \\
\text { conditions }\end{array}$ & LC-MS & $\begin{array}{c}\text { Isolevuglandins (IsoLGs)-, MDA-, } \\
\text { 4.HNE-, } N \text {-Acyl-, and } \\
N \text {-carboxyacyl-PEs }\end{array}$ & [71] \\
\hline \multicolumn{4}{|c|}{ In vivo Studies } \\
\hline hLDL & Fluorimeter & $\begin{array}{l}\text { Fluorescent chromophores AGEs-lipids } \\
\qquad(\mathrm{Ex} 360 \mathrm{~nm}, \mathrm{Em} 440 \mathrm{~nm})\end{array}$ & [72] \\
\hline Rat liver aminophospholipids & GC-MS & $\begin{array}{l}\text { Amadori aminophospholipids (as } \\
\text { 5-(hydroxymethyl)-2-furfuraldehyde; } \\
\text { 5-HMF) }\end{array}$ & [73] \\
\hline $\begin{array}{c}\text { Liver mitochondria from mammalian } \\
\text { species }\end{array}$ & GC-MS & $\begin{array}{l}\text { Carboxymethyl-ethanolamine } \\
\text { (as marker of CM-PE) }\end{array}$ & [74] \\
\hline hRBCs & $\begin{array}{l}\text { TLC, HPLC, NMR, } \\
\text { FAB-MS }\end{array}$ & Deoxy- $D$-fructosyl PE & [56] \\
\hline RBC membranes & GC-MS & $\begin{array}{l}\text { Glycation and carboxymethylation of } \\
\text { aminophospholipids (PE and PS) }\end{array}$ & [75] \\
\hline $\begin{array}{l}\text { Glucose/lactose }+ \text { PE; foods and biological } \\
\text { samples } \\
\text { Presence in foods (e.g., infant formula, } \\
\text { chocolate) and in rat plasma }\end{array}$ & $\begin{array}{l}\text { HPLC-UV (labeling } \\
\text { with 3-methyl-2- } \\
\text { benzothiazolinone } \\
\text { hydrazone) }\end{array}$ & Glycated-PE and lactose-PE & [76] \\
\hline $\mathrm{RBC}$ and $\mathrm{LDL}$ & LC-MS and NMR & $N$-(hexanoyl)ethanolamine & [63] \\
\hline
\end{tabular}


Much evidence demonstrates the in vitro and in vivo occurrence of the Schiff base, Amadori and AGEs-lipid products resulting from the Maillard reaction (see also Table 1 and Figure 3). The Schiff base formation between glucose and aminophospholipids was documented in experimental models and in human RBC membranes, plasma, and low-density lipoproteins (LDL) [53,77-79]. The existence of glycated aminophospholipids in its Schiff base form was confirmed by using HPLC LC-electrospray ionization (ESI)-MS. Reduction with $\mathrm{NaBH}_{3} \mathrm{CN}$, shifting the retention time and increasing the detected mass of glycated lipids by two units, confirmed the identity of the major analyte as a Schiff base. Surprisingly, only the diacyl species became glycated and neither the alkylacyl nor the alkenylacyl were modified; furthermore, in contrast with in vitro experiments, PS glycation was not detected.

Figure 3. Advanced glycation end products (AGEs)-lipid products resulting from the Maillard reaction.

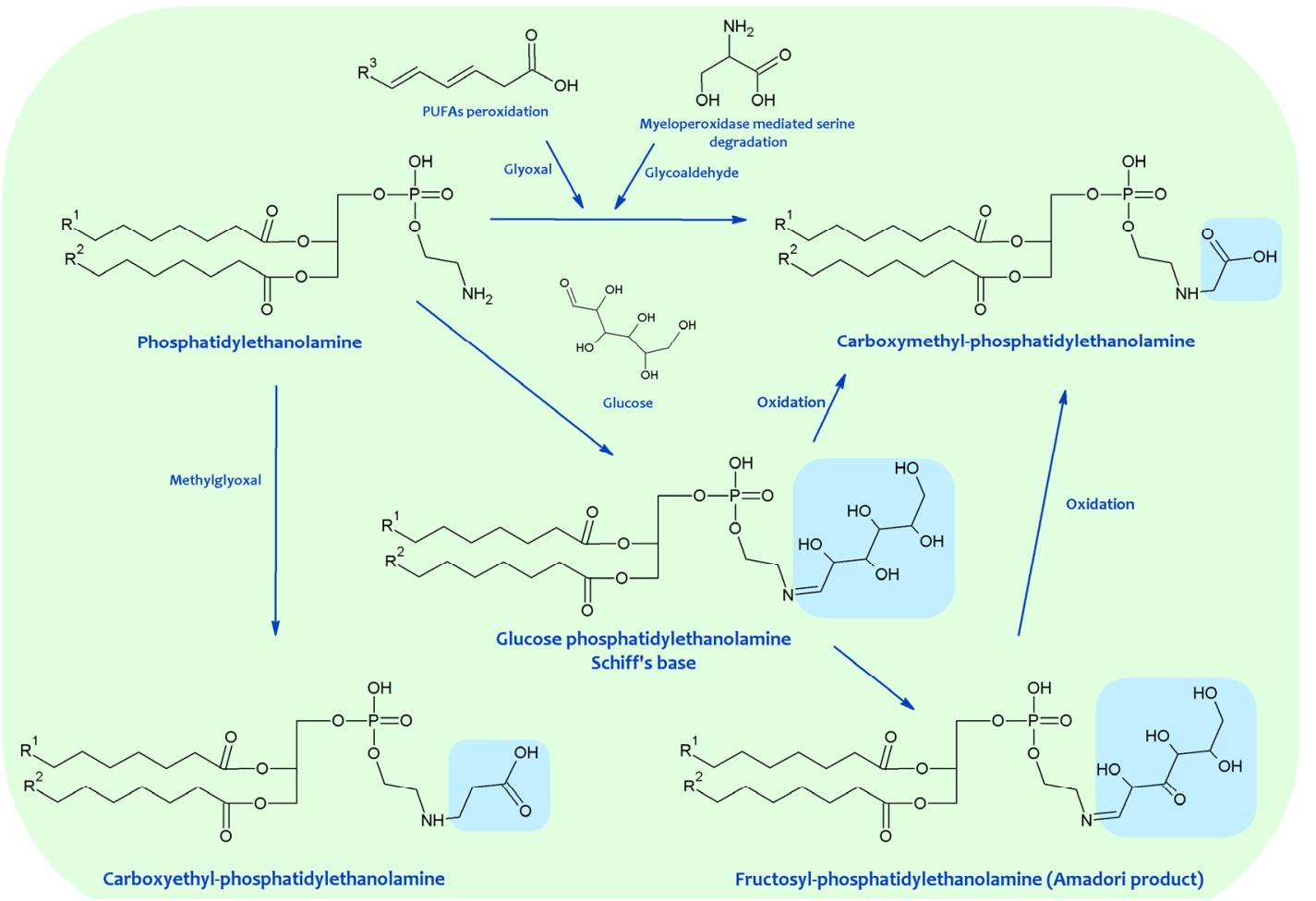

In vitro model reactions of D-glucose and $\mathrm{PE}$ demonstrated the formation of Amadori products, which were also detected in vivo [55-58,73]. Chromatographic and spectroscopic characterization unequivocally proved the existence of deoxy-D-fructosyl PE [55,56]. The formation of the Amadori product has also been demonstrated through the synthesis and characterization of $N$-(glucitol)ethanolamine (GE), a stable reduction product of glycated PE, detected in RBC membranes [58]; and by 5-(hydroxymethyl)-2-furfuraldehyde formation from the acid-treated phospholipid fraction as a stable derivative of an Amadori product, in this case being detected in rat liver lipid extracts [73].

Early immunological studies indicated the presence of MRPs covalently attached to aminophospholipids such as PE in LDL, although their structures remain unknown [72]. In addition, by using an ELISA assay, it was concluded that the majority of MRPs present in LDL were localized in the lipid phase. Nevertheless, subsequent analyses identified carboxymethyl-lysine (CML) as the 
major AGE antigen in tissue proteins, and it was proposed that AGE-lipids could be actually immunologically cross-reactive carboxymethyl (CM) derivatives of PE and PS formed by phospholipid glyco- and lipoxidation, similarly to proteins [80]. So, by using a selected selective ion monitoring-gas chromatography-Mass spectrometry (SIM-GC-MS) assay for carboxymethylethanolamine (CME) [54,74,75,81] and carboxymethylserine (CMS) [58], the hydrolysis products of CM-PE and CM-PS, respectively, it was possible to demonstrate CME and CMS formation in vitro during the glycation of dioleoyl-PE under air and from linoleoylpalmitoyl-PE, but not from dioleoyl-PE, in absence of glucose. These data seem to indicate that carboxymethylation may proceed either from glucose or PUFA under oxidizing conditions. In experimental models, glucose, which is more resistant to autoxidation than PUFAs, was present at a 33-fold molar excess over free amino groups, whereas PUFA (linoleic acid) in PE was present in equimolar amounts with the amino group. So, it is difficult to anticipate which one of the routes, glycoxidation or lipoxidation, predominates in vivo, being CME and CMS, like CML [82], mixed AGEs and ALEs. The possible contribution of myeloperoxidase-catalyzed formation of $\mathrm{CM}$ groups from serine interaction with hypochlorite should not be dismissed [83]. In this line, it the possible contribution of PS moieties to glycoaldehyde generation, as precursor of CM groups, might be hypothesized. An alternative source of these compounds could be the oxidative cleavage of the Amadori compounds that would result from glycation of PE or PS. However, glycated PS has not been detected in vivo. CME and CMS were detected in RBC and liver mitochondria membranes, and also in urine [54,74,75,81].

The Maillard reaction can generate free radicals through autoxidative processes that, in turn, lead to protein damage [28]. Similarly, these processes, initially described for proteins, may be expanded to aminophospholipids, representing another mechanism for the initiation of lipid oxidation (see Table 2). Accordingly, much evidence indicates that the Maillard reaction on aminophospholipids enhances lipid peroxidation: (i) Autoxidation is usually accelerated by primary amines [52]; (ii) in liposomes, inclusion of PE was found to accelerate the $\mathrm{Fe}^{2+}$-dependent peroxidation [52]; (iii) in vitro, highest levels of fluorescence intensity were obtained by incubating dilinoleoyl-PE with glucose in oxidative conditions; dipalmitoyl-PE and dilinoleoyl- or dipalmitoyl-PC were ineffective in fluorescence generation independently of the presence/absence of glucose and oxidative conditions [84]; (iv) the presence of a carboxyl group on PS, or two in the case of carboxymethylated serine, may enhance its metal binding capacity, leading to increased metal-catalyzed lipid peroxidation [58]; (v) even in the absence of exogenously added transition metals or free radical generating systems, the formation of AGE-lipids is accompanied by oxidation of the unsaturated fatty acid side chains, suggesting that AGEs formation is a source of free radicals that leads to lipid oxidation [85]; and finally, (vi) the incorporation of glycated PE into LDL facilitates its peroxidation [79].

Despite the fact that non-enzymatic modification of aminophospholipids by glycation, carboxymethylation and lipid peroxidation has been described, they represent only a limited range of the possible products that can likely be formed by the Maillard reaction. 
Table 2. Summary of studies on physico-chemical effects of non-enzymatic aminophospholipid modification by carbonyl-amine reactions.

\begin{tabular}{|c|c|c|c|c|}
\hline $\begin{array}{c}\text { In vitro or in vivo } \\
\text { experimental model }\end{array}$ & $\begin{array}{l}\text { Analytical } \\
\text { approach }\end{array}$ & Marker & Finding & Ref. \\
\hline Rat and human urine & $\begin{array}{l}\text { NMR and } \\
\text { HPLC }\end{array}$ & $N$-2-(Propenal)serine & $\begin{array}{c}\text { Direct evidence for oxidative } \\
\text { decomposition of phospholipids } \\
\text { by lipid peroxidation }\end{array}$ & {$[50]$} \\
\hline Rat and human urine & $\begin{array}{l}\text { NMR and } \\
\text { HPLC }\end{array}$ & $N$-(2-propenal)ethanolamine & $\begin{array}{c}\text { Direct evidence for oxidative } \\
\text { decomposition of phospholipids } \\
\text { by lipid peroxidation }\end{array}$ & {$[51]$} \\
\hline Glucose + PE/hLDL & Fluorimeter & $\begin{array}{l}\text { Fluorescent lipid advanced } \\
\text { glycosylation } \\
(\text { Ex } 360 \mathrm{~nm}, \text { Em } 440 \mathrm{~nm})\end{array}$ & $\begin{array}{c}\text { Increase of fluorescence } \\
\text { associated with the progressive } \\
\text { oxidative modification of } \\
\text { unsaturated fatty acid residues }\end{array}$ & {$[72]$} \\
\hline $\begin{array}{l}\text { Lipids (PE and PS) and } \\
\text { hLDL-advanced } \\
\text { glycosylation }\end{array}$ & GC-MS & $\begin{array}{l}\text { 4-hydroxyhexenal and } \\
\text { 4-hydroxynonenal }\end{array}$ & $\begin{array}{l}\text { Lipids-AGE formation in close } \\
\text { proximity to unsaturated fatty acyl } \\
\text { groups leads to lipid peroxidation }\end{array}$ & {$[85]$} \\
\hline $\begin{array}{l}\text { Unilamellar vesicles } \\
\text { with PE and PC + } \\
\text { glyceraldehyde }\end{array}$ & $\begin{array}{l}\text { Time- } \\
\text { resolved } \\
\text { fluorescence } \\
\text { spectroscopy }\end{array}$ & & $\begin{array}{l}\text { Aminophospholipid glycation } \\
\text { increases the head-group hydration } \\
\text { and lipid order in both regions of } \\
\text { the membrane and lipid glycation } \\
\text { is accompanied of lipid oxidation }\end{array}$ & {$[86]$} \\
\hline $\begin{array}{l}\text { Atherosclerotic plaques } \\
\text { collected from both } \\
\text { diabetic and } \\
\text { non-diabetic subjects }\end{array}$ & LC-ESI-MS & Glycated PE & $\begin{array}{l}\text { Glycated aminophospholipids are } \\
\text { the major LDL glycation products } \\
\text { and increase LDL susceptibility to } \\
\text { oxidation }\end{array}$ & {$[87]$} \\
\hline $\begin{array}{l}\text { Model systems and egg } \\
\text { yolk products }\end{array}$ & LC-ESI-MS & $\begin{array}{c}\text { Identification of } \\
\text { PE-linked glucosylamines } \\
\text { (Schiff-PE), Amadori } \\
\text { products (Amadori-PE), } \\
\text { 5-hydroxymethylpyrrole-2- } \\
\text { carbaldehydes (Pyrrole-PE), } \\
\text { and carboxymethyl- (CM-PE) } \\
\text { as well as carboxyethyl- } \\
\text { (CE-PE) derivatives }\end{array}$ & $\begin{array}{l}\text { Possible influence on emulsifying } \\
\text { properties and oxidation resistance }\end{array}$ & [88] \\
\hline $\begin{array}{c}\text { Amadori-PE }+ \text { linoleic } \\
\text { acid }\end{array}$ & $\begin{array}{l}\text { LC-MS and } \\
\text { colorimetry }\end{array}$ & $\begin{array}{l}\text { TBARs and lipid } \\
\text { hydroperoxides }\end{array}$ & $\begin{array}{c}\text { Glycated-PE trigger lipid } \\
\text { peroxidation via free radical } \\
\text { reactions }\end{array}$ & [89] \\
\hline $\begin{array}{l}\text { RBCs from diabetic and } \\
\text { healthy individuals }\end{array}$ & LC-ESI-MS & $\begin{array}{c}\text { Schiff-PEs and } \\
\text { Amadori-PEs, and detection } \\
\text { of pyrrole-PE, CM-PE and } \\
\text { CE-PE }\end{array}$ & $\begin{array}{c}\text { Increase in diabetes; glycated PE } \\
\text { promotes lipid peroxidation of } \\
\text { biomembranes }\end{array}$ & {$[90]$} \\
\hline
\end{tabular}


Table 2. Cont.

\begin{tabular}{|c|c|c|c|c|}
\hline $\begin{array}{l}\text { In vitro or in vivo } \\
\text { experimental model }\end{array}$ & $\begin{array}{c}\text { Analytical } \\
\text { approach }\end{array}$ & Marker & Finding & Ref. \\
\hline $\begin{array}{c}\text { Different species of } \\
\mathrm{PE}+4-\mathrm{HNE} / 4-\mathrm{HDDE} / \\
\text { 4-HHE }\end{array}$ & $\begin{array}{l}\text { GC-MS, } \\
\text { TLC, HPLC, } \\
\text { and NMR }\end{array}$ & Aldehydes-PE & $\begin{array}{l}\text { Different PE species are } \\
\text { differently targeted by fatty } \\
\text { aldehydes: the higher their } \\
\text { hydrophobicity, the higher the } \\
\text { amount of adducts made }\end{array}$ & [64] \\
\hline $\begin{array}{c}\mathrm{PE} / \mathrm{PC} \text { monolayers }+ \\
\text { 4-HNE }\end{array}$ & $\begin{array}{l}\text { Alternating } \\
\text { current (AC) } \\
\text { polarography }\end{array}$ & $\begin{array}{l}\text { Physico-chemical state of a } \\
\text { condensed PE-containing } \\
\text { phospholipid monolayer and } \\
\text { its interaction with apo A-I }\end{array}$ & $\begin{array}{c}\text { 4.HNE-PE does not alter } \\
\text { monolayer stability, but decreases } \\
\text { apo A-I insertion into the } \\
\text { monolayer }\end{array}$ & [91] \\
\hline $\begin{array}{l}\mathrm{PC} / \mathrm{PE} \text { mixture }+ \\
\text { Glucose }+ \text { isolated } \\
\text { membrane proteins }\end{array}$ & $\begin{array}{l}\text { Lipid-protein } \\
\text { interactions }\end{array}$ & $\begin{array}{c}\text { Amadori-PE and } \\
\text { Amadori-proteins, and } \\
\text { lipid-protein interaction } \\
\text { parameters }\end{array}$ & $\begin{array}{l}\text { Lipid glycation decreases the } \\
\text { affinity of lipids for membrane } \\
\text { proteins, induces structural } \\
\text { rearrangements in the protein that } \\
\text { makes it more sensitive to thermal } \\
\text { unfolding and decreases the } \\
\text { affinity between proteins and the } \\
\text { surrounding phospholipids. }\end{array}$ & [92] \\
\hline $\begin{array}{c}\mathrm{PE}+\text { Glucose }+ \\
\text { oxidative conditions }\end{array}$ & LC-ESI-MS & $\begin{array}{c}\text { Glycated-PE }+ \text { oxidation } \\
\text { products }\end{array}$ & $\begin{array}{l}\text { Oxidation of glycated-PE occurred } \\
\text { more quickly than the oxidation of } \\
\text { non-glycated-PE probably because } \\
\text { of the existence of more oxidation } \\
\text { sites derived from glycation of } \\
\text { polar head group. }\end{array}$ & [93] \\
\hline $\begin{array}{c}\mathrm{PE}+\text { Glucose }+ \\
\text { oxidative conditions }\end{array}$ & LC-MS-MS & $\begin{array}{l}\text { Identification of free } \\
\text { radicals in oxidized and } \\
\text { glycoxidized PE }\end{array}$ & $\begin{array}{l}\text { Presence of several sites } \\
\text { susceptible to oxidation in } \\
\text { glycated-PE which may be } \\
\text { responsible for the increase in the } \\
\text { oxidative reaction rate occurring } \\
\text { in glycated compounds }\end{array}$ & [94] \\
\hline
\end{tabular}

\section{Biological Significance of MRPs in Aminophospholipids}

The membrane lipid bilayer is not a simple permeability barrier and matrix for protein organization, but a dynamic component capable of initiating and maintaining essential metabolic processes. Considering the presence of free amino groups in aminophospholipids, and their ubiquity in all the biomembranes, a priori all of them may be modified by the Maillard reaction. In this way, biological processes involving aminophospholipids could be potentially affected by this non-enzymatic process. Among these, the following may be highlighted [1,3,4,12]: (i) Asymmetrical distribution of aminophospholipids in cellular and different subcellular membranes; (ii) translocation and lateral diffusion in the membrane; (iii) membrane physical properties; (iv) biosynthesis and turnover of membrane phospholipids; and (v) activity of membrane-bound proteins that require aminophospholipids for their function (see Figure 4 and Table 3). 
Figure 4. Potential effects of aminophospholipid modification by carbonyl-amine reactions in biological membranes.

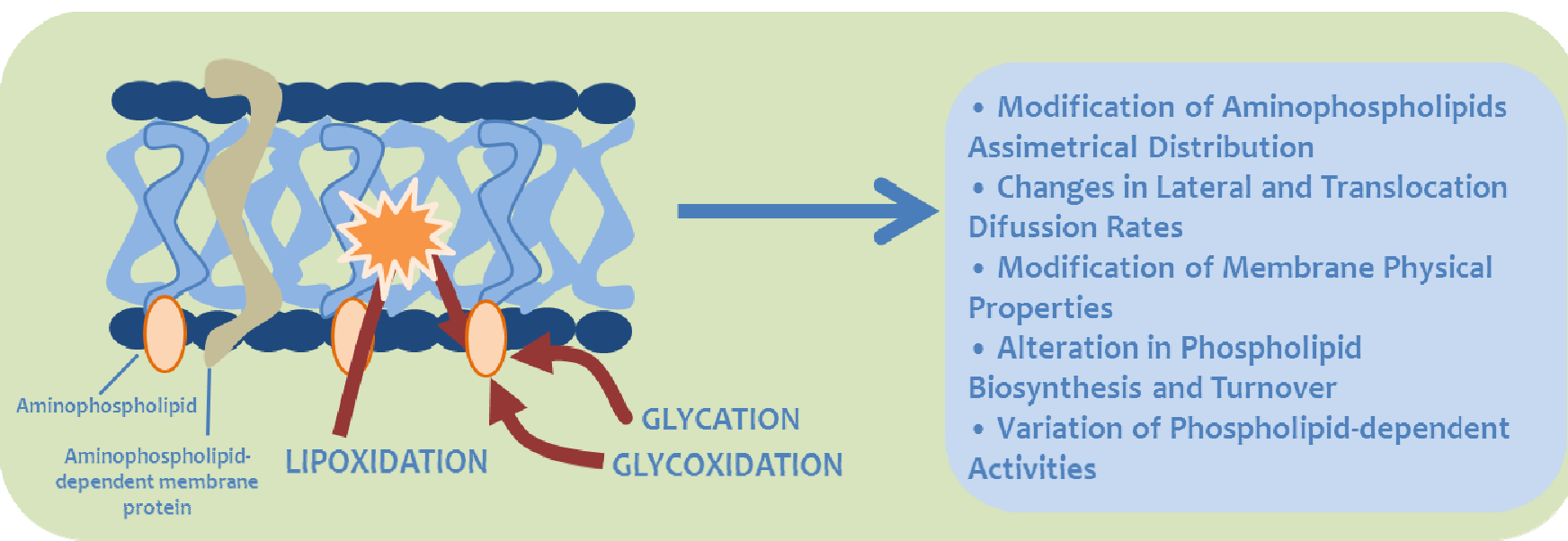

Table 3. Summary of studies on biological effects of non-enzymatic aminophospholipid modification by carbonyl-amine reactions.

\begin{tabular}{|c|c|c|c|c|}
\hline Experimental model & $\begin{array}{l}\text { Analytical } \\
\text { approach }\end{array}$ & Marker & Finding & Reference \\
\hline $\begin{array}{l}\mathrm{MDA}+\mathrm{RBCs} \text { and } \\
\text { in vitro lipid } \\
\text { peroxidation of } \mathrm{RBC}\end{array}$ & TLC & $\begin{array}{l}\text { MDA:phospholipid } \\
\text { adducts }\end{array}$ & $\begin{array}{c}\text { Lipid peroxidation and MDA } \\
\text { accumulation disturb organization of PS } \\
\text { and PE in the human erythrocyte } \\
\text { membrane bilayer }\end{array}$ & {$[38]$} \\
\hline $\begin{array}{c}\text { Erythrocytes of } \\
\text { phenylhydrazine-treated } \\
\text { rats }\end{array}$ & TLC & $\begin{array}{l}\text { MDA:phospholipid } \\
\text { adducts }\end{array}$ & $\begin{array}{l}\text { Externalization of PS and PE in the } \\
\text { membrane bilayer and hypercoagulability }\end{array}$ & [39] \\
\hline Glucose-treated RBC & TLC & $\begin{array}{l}\text { MDA:phospholipid } \\
\text { adducts }\end{array}$ & $\begin{array}{l}\text { Increase adduct formation and osmotic } \\
\text { fragility in human RBCs }\end{array}$ & {$[42]$} \\
\hline $\begin{array}{l}\text { hRBCs from different } \\
\text { age groups + MDA or } \\
\mathrm{H} 2 \mathrm{O} 2 \text { treatment }\end{array}$ & & $\begin{array}{l}\text { Aminophospholipid } \\
\text { translocase activity }\end{array}$ & $\begin{array}{l}\text { Decrease with age (defects in endogenous } \\
\text { lipid asymmetry observed in aged human } \\
\text { RBCs may be due to altered activity of the } \\
\text { translocase) }\end{array}$ & {$[95]$} \\
\hline $\begin{array}{c}\text { Lipid extracts from } \\
\text { platelet incubated PE }+ \\
\text { PS + 4-HNE }\end{array}$ & LC-MS & $\begin{array}{l}\text { PE-4-HNE } \\
\text { compounds }\end{array}$ & $\begin{array}{c}\text { Formation in cell membranes that could } \\
\text { alter the phospholipase-dependent cell } \\
\text { signalling }\end{array}$ & {$[46]$} \\
\hline $\begin{array}{l}\text { Glycated-PE LDL + } \\
\text { THP1 cells } \\
\text { (macrophages) }\end{array}$ & $\begin{array}{l}\text { Cell culture, } \\
\text { LC-ESI-MS }\end{array}$ & Glycated PE & $\begin{array}{l}\text { Glycated-PtdEtn promotes macrophage } \\
\text { uptake of LDL and accumulation of } \\
\text { cholesteryl esters and triacylglycerols }\end{array}$ & [79] \\
\hline $\begin{array}{l}\text { Oxidized-LDL }+ \\
\text { platelets }\end{array}$ & TLC & Aldehyde-PE & $\begin{array}{l}\text { Modified PE as the active component of } \\
\text { oxidized LDL particles elicit a pronounced } \\
\text { prothrombotic response by increasing the } \\
\text { activity of the platelet prothrombinase } \\
\text { complex }\end{array}$ & [96] \\
\hline
\end{tabular}


Table 3. Cont.

\begin{tabular}{|c|c|c|c|c|}
\hline Experimental model & $\begin{array}{l}\text { Analytical } \\
\text { approach }\end{array}$ & Marker & Finding & Reference \\
\hline $\begin{array}{l}\text { PE + 4-HNE and 4- } \\
\text { HDDE (4-hydroxy- } \\
\text { 2E,6Z-dodecadienal) }\end{array}$ & $\begin{array}{l}\text { TLC and } \\
\text { GLC }\end{array}$ & $\begin{array}{l}\text { 4-HNE-PE and } \\
\text { 4-HDDE-PE }\end{array}$ & $\begin{array}{l}\text { Modified PE is poor substrate for secreted } \\
\text { phospholipase A2 }\end{array}$ & [97] \\
\hline Human Plasma & $\begin{array}{l}\text { TLC and } \\
\text { GLC }\end{array}$ & $\begin{array}{l}\text { 4-HNE-PE and } \\
\text { 4-HDDE-PE }\end{array}$ & $\begin{array}{l}\text { Potential alteration of phospholipid- } \\
\text { dependent cell signaling }\end{array}$ & [97] \\
\hline $\begin{array}{l}\text { Amadori-PE }+ \\
\text { endothelial cells } \\
\text { (HUVEC) }\end{array}$ & Cell culture & $\begin{array}{l}\text { Cell proliferation, } \\
\text { migration, and tube } \\
\text { formation, and } \\
\text { secretion of matrix } \\
\text { metalloproteinase } 2 \\
\text { (MMP-2) }\end{array}$ & $\begin{array}{c}\text { Glycated-PE promotes vascular disease as } \\
\text { a result of its angiogenic activity on } \\
\text { endothelial cells }\end{array}$ & {$[98,99]$} \\
\hline Human blood platelets & GC-MS & $\begin{array}{l}\text { 4-HHE-, 4-HNE-, } \\
\text { and 4-HDDE-PE }\end{array}$ & $\begin{array}{c}\text { In vivo identification. } \\
\text { Increase of platelet aggregation }\end{array}$ & [100] \\
\hline
\end{tabular}

A particularly interesting property of biomembranes is the asymmetric distribution of phospholipids across the bilayer. This is especially evident for the aminophospholipids, PS and PE, which are preferentially located in the membranes' inner leaflet. Since choline phospholipids are generally more saturated than aminophospholipids, this asymmetry is accompanied by a non-random distribution of fatty acyl side-chains as well. Aminophospholipid asymmetry is controlled by specific mechanisms involving an ATP and $\mathrm{Ca}^{2+}$ dependent inward-directed pump known as aminophospholipid translocase, specific for the polar head group [12]. This suggests that the biogenesis and maintenance of the phospholipid asymmetry are important components of membrane homeostasis. So, defects in the normal asymmetric distribution of aminophospholipids may result in altered membrane surface properties that may have important physiological and pathophysiological consequences. As prominent examples of this, one could find the consequences in hemostasis and thrombosis due to exposed PS in activated platelets, and the apparent recognition and sequestration of PS-expressing cells by the reticuloendothelial system [11,39]. Abnormal distributions of aminophospholipids have been also reported for sickle [37] and iron deficient [36] cells, old RBC [35,40], RBC obtained from neonates, patients with chronic myeloid leukemia and diabetes mellitus [41,42], and also in tumorigenic and apoptotic cells [101]. The origin of perturbed aminophospholipid asymmetry in these pathologic cells is unclear, but it might be related to the aminophospholipid nonenzymatic modification described in some of these situations.

PE constitutes a class of lipids, that when dispersed in pure form under physiological conditions, assemble into nonbilayer structures [102]. This contrast to lamellar phase-forming lipids, which readily form hydrated lamellar phases or bilayer structures when dispersed in aqueous media [102]. Lipids with a high propensity to form nonlamellar phases have been implicated in supporting transient local nonbilayer structures, which occur in some cellular processes such as transmembrane movement of ions and large molecules, membrane fusion, membrane enzymatic functions and cell division. However, at present no data are available on the effects of MRP-lipids in these properties. 
Theoretically, aminophospholipid biosynthesis and degradation could also be affected by the Maillard reaction: PS is considered both an end product and a biosynthetic intermediate, since it serves as a precursor of PE, given that in eukaryotes, this phospholipid can be formed either by decarboxylation of PS - the major pathway for PE biosynthesis — or through incorporation of ethanolamine into PE via the CDP-ethanolamine pathway. PS synthase is located in the endoplasmic reticulum, whereas PS decarboxylase is strictly confined to the inner mitochondrial membrane, an important finding when accounting aminophospholipid modification in mitochondrial membranes. Finally, PE can be converted into PC by a PE $N$-methyltransferase, constituting a relevant pathway for PC biosynthesis. The consequences of the interference of biosynthetic pathways, if any, that result from the non-enzymatic modification of the polar head of aminophospholipids, remain unknown. How the Maillard reaction - on aminophospholipids - may affect the recognition and transport to other cellular or subcellular membranes by aminophospholipids-binding proteins is also unanswered. In contrast, some data are available from in vitro experiments, indicating alterations of the degradative pathway [56]. So, it was described that the hydrolysis of glycated PE by phospholipase $\mathrm{A}_{2}$ was not affected, but the hydrolysis by phospholipase $\mathrm{C}$ and $\mathrm{D}$ was reduced by $50 \%$, in agreement with the fact that glycation affects the polar head but not the acylester bound.

Although several membrane-bound proteins from different biomembranes possibly require aminophospholipids for their function, this fact could be particularly relevant for mitochondrion membranes because several electron transport chain complexes, such as Complex I, Complex III, Complex IV; and the adenine-nucleotide translocator, require binding or interaction with PE [103]. Thus, an increase in the levels of mitochondrial MRPs-lipids, e.g., CME, may lead to serious alterations in mitochondrial respiration and energy production.

The potential effects of these modifications introducing changes in the structural organization of the lipid bilayer and/or changes in the physico-chemical and biological properties of the polar head of aminophospholipids remain to be extensively explored. Nevertheless, considering the serious alterations that can be derived from these non-enzymatic modifications, a priori, it can be expected that the levels of these modifications should be found in a low range, at least, in physiological conditions.

\section{Physiological Significance of MRPs in Lipids}

Studies reporting the levels of MRP-lipids in different biomembranes are limited, with RBC membranes being the more extensively studied model. For human RBC and plasma lipids, 1.2\% and $2.3 \%$, respectively, of total PE in glycated form, were reported [77]. In another study, concentrations of glycated PE of $9 \%$ and $15 \%$ were described for RBC and plasma lipids [56]. However, this modification degree, considering that during the preparation and manipulation of lipids prior to analysis Schiff bases were not discharged, may be the result of an overestimation in the percentage of modified PE. Accordingly, the Amadori adducts measurement by GC-MS in aminophospholipids from human $\mathrm{RBC}$ revealed a concentration of $0.41 \pm 0.11 \mathrm{mmol} / \mathrm{mol}$ ethanolamine, representing $0.03 \%$ in the glycated form of total PE [58]. With reference to AGE-lipids, only aminophospholipid carboxymethylation, namely CME and CMS formation, was quantified. So, the measurement of CME in human RBCs revealed a value of $0.14 \mathrm{mmol} / \mathrm{mol}$ ethanolalmine [54]. CMS was present at an about 
three times higher concentration (0.44 $\mathrm{mmol} \mathrm{CMS} / \mathrm{mol}$ serine) [58]. So, CME was quantitatively a minor fraction of total ethanolamine, representing only about $0.01 \%$ of the modification of $\mathrm{RBC}$ membrane phospholipids, in agreement with data reported for phospholipid-MDA adducts representing $0.06 \%-0.08 \%$ of total PE and PS (equivalent to $0.2 \%$ of total phospholipids) [40-42].

In urine, CME, CMS, MDA-ethanolamine (MDA-Etn), and MDA-ser were detected [50,51,54,58]; however, only the levels of CME [54] and MDA-Etn [51] were available. So, it was calculated that approximately $2.8 \mu \mathrm{mol}$ of CME $(300 \mu \mathrm{g})$ and $0.07 \mu \mathrm{mol}$ MDA-Etn $(5 \mu \mathrm{g})$ were excreted daily by a healthy human adult (considering a mean daily creatinine excretion of $1.4 \mathrm{~g}$ for a $70 \mathrm{~kg}$ subject).

Based on the concentration of $\mathrm{CME}$ and MDA-Etn in RBC ghost membranes, $\sim 0.14$ and $0.98 \mathrm{mmol} / \mathrm{mol}$ of $\mathrm{PE}$, respectively, and the concentration of PE in RBC membranes, $\sim 1 \mathrm{mg} / \mathrm{mL}$ of packed RBC (average molecular mass for PE, $800 \mathrm{Da}$ ), $0.18 \mathrm{nmol}$ of $\mathrm{CME} / \mathrm{mL}$ and $1.22 \mathrm{nmol}$ of MDA-Etn/mL of packed erythrocytes can be estimated. Since the average $70 \mathrm{~kg}$ subject has about $2 \mathrm{~L}$ of packed red cells and $\sim 1 \%$ of red cell turnover/day (average red cell life span, 120 days), only about $4 \mathrm{nmol}$ of the daily urinary excretion of CME, and $24 \mathrm{nmol}$ of MDA-Etn, can be attributed to RBC membrane degradation. Anticipating that other modifications may be present in a similar extent, it may be estimated that $\mathrm{RBC}$ modifications only represent $1 \%-5 \%$ of the total recovered daily in urine. Consequently more than $95 \%$ may arise from the physiological turnover of membrane phospholipids in cells other than red cells, supposing the non-existence of dietary income.

Accordingly, a concentration of $0.11 \mathrm{mmol}$ of Amadori products/mol PE was found in the isolated lipid fractions from rat livers, representing a modification degree of about $0.008 \%-0.01 \%$ [73]. Furthermore, with the mitochondrion being the major site of reactive species production in the cell, it could be hypothesized that aminophospholipids from mitochondrial membranes could be damaged by carbonyl stress. Thus, CME from mitochondrial phospholipids was evidenced in ten mammalian species. The levels observed indicated that CME is quantitatively a minor fraction of total PE, representing only about $0.025 \%-0.035 \%$ modification of mitochondrial membrane phospholipids (considering that all animals are male young adults, and assuming that the mitochondrial phosphatidylethanolamine average is about 35\%) [74].

The average inner-membrane surface area per mitochondrion $\left(12.43 \mu \mathrm{m}^{2}\right)$, when multiplied by the average number of mitochondria per cell $(n=1312)$, shows that the average total inner-membrane surface area in the cell is nearly 11 -fold greater than the cell surface area, despite the fact that the mitochondria occupy only $17 \%$ of the total cell volume [104]. In the adult rat, the total mitochondrial inner-membrane surface area in the major organs has been found to average $460 \mathrm{~m}^{2}$, contributed mainly by skeletal muscle ( $82 \%$ of the total), liver $(8 \%)$, kidney $(5 \%)$, heart $(3 \%)$, brain $(1 \%)$, and lung (1\%) (59). On the other hand, recent studies in liver cell sindicate an average mitochondrial half-life of 3.8 days, corresponding to the destruction of one mitochondrion per cell about every $11 \mathrm{~min}$. Similar conclusions apply in the case of kidney and heart muscle, both indicating that mitochondria are replaced many times during the lifetime of a given cell [104]. Hence, it can be inferred that cellular membranes, and particularly mitochondrial aminophospholipids, might be the major source of MRP-lipids in plasma and urine. In any case, and due to their low levels, it seems likely that MRP-lipids should be considered as biomarkers rather than important effectors of damage in tissues, at least in physiological conditions. 


\section{Significance of MRPs in Aminophospholipids in Aging and Pathological Conditions}

Similarly to proteins, MRP-lipids are of interest due to their potential contribution to the physiology of the aging process and age-associated diseases, such as diabetes and atherosclerosis (see Table 4). There is little evidence that demonstrates MRP-lipid accumulation in biological membranes during aging and lifespan. Examining the occurrence of phospholipid-MDA adducts in human RBCs and eye lenses of diverse ages, it was demonstrated that aged RBC showed significantly higher modifications than young erythrocytes $(1.5 \%$ versus $0.2 \%)$ [35,40,96], similar to the results obtained for human cataractous lenses $[43,44]$. Furthermore, lipofuscin - a yellowish brown, lipid-rich, heterogeneous, cytoplasmic granule-shares characteristic autofluorescence with MDA-aminophospholipids, accumulating in a variety of animal tissues, particularly in metabolically active post-mitotic tissues, such as brain and heart, during their aging [34].

Table 4. Summary of studies on physiological and pathological effects of non-enzymatic aminophospholipid modification by carbonyl-amine reactions.

\begin{tabular}{|c|c|c|c|c|}
\hline Experimental model & $\begin{array}{l}\text { Analytical } \\
\text { approach }\end{array}$ & Marker & Finding & Reference \\
\hline Aged RBC & Fluorimeter & $\begin{array}{l}\text { Fluorescent chromophores } \\
\qquad \begin{array}{c}\text { (Ex 390-400 nm, } \\
\text { Em } 460 \mathrm{~nm})\end{array}\end{array}$ & $\begin{array}{c}\text { Increase with aging } \\
\text { Altered physical and } \\
\text { biochemical properties of } \\
\text { aging cells (polymerization of } \\
\text { plasma membrane proteins) }\end{array}$ & {$[35]$} \\
\hline $\begin{array}{l}\text { Lipids extracts from } \\
\text { different tissues (heart, } \\
\text { brain, liver, testis, kidney, } \\
\text { adrenal cortex) }\end{array}$ & Fluorimeter & Fluorescent chromophores & $\begin{array}{l}\text { Increase with aging, and in } \\
\text { pathological conditions } \\
\text { (e.g., diabetes, hyperlipidemia) }\end{array}$ & {$[15,34]$} \\
\hline $\begin{array}{l}\text { RBC fromiron-deficient } \\
\text { infants and animals }\end{array}$ & $\begin{array}{c}\text { Thin Layer } \\
\text { Chromatography } \\
\text { (TLC) }\end{array}$ & $\begin{array}{l}\text { Schiff's base adduct due to } \\
\text { reaction MDA + PS/PE }\end{array}$ & Decrease RBC survival & {$[36]$} \\
\hline $\begin{array}{c}\text { RBC from the "sickle cell } \\
\text { disease" }\end{array}$ & $\begin{array}{l}\text { Fluorimeter and } \\
\text { TLC }\end{array}$ & $\begin{array}{l}\text { Fluoresecent chromophores } \\
\text { \& MDA:aminophospholipid } \\
\text { adducts }\end{array}$ & $\begin{array}{l}\text { Increase adduct formation in } \\
\text { sickle cell disease }\end{array}$ & {$[37]$} \\
\hline $\begin{array}{l}\text { Lipid extracts of the human } \\
\text { cataractous and normal } \\
\text { lenses }\end{array}$ & $\begin{array}{l}\text { Fluorimeter and } \\
\text { TLC }\end{array}$ & $\begin{array}{l}\text { Fluoresecnt chromophores } \\
\text { (Ex } 365 \text { nm, Em } 460 \mathrm{~nm} \text { ) } \\
\text { and MDA: } \\
\text { aminophospholipid adducts }\end{array}$ & $\begin{array}{c}\text { Increase in human senile } \\
\text { cataract }\end{array}$ & [43] \\
\hline $\begin{array}{l}\text { Aged human RBC } \\
\text { membranes }\end{array}$ & $\begin{array}{l}\text { Fluorimeter and } \\
\text { TLC }\end{array}$ & $\begin{array}{c}\text { Fluorescent chromophores \& } \\
\text { MDA: aminophospholipid } \\
\text { adducts }\end{array}$ & Increase with aging & {$[40]$} \\
\hline RBC from diabetic patients & TLC & MDA:phospholipid adducts & Increase adducts in diabetes & [41] \\
\hline
\end{tabular}


Table 4. Cont.

\begin{tabular}{|c|c|c|c|c|}
\hline Experimental model & $\begin{array}{l}\text { Analytical } \\
\text { approach }\end{array}$ & Marker & Finding & Reference \\
\hline $\begin{array}{l}\text { humanRBC (hRBC) from } \\
\text { different age groups }+ \\
\text { MDA or } \mathrm{H}_{2} \mathrm{O}_{2} \text { treatment }\end{array}$ & & $\begin{array}{l}\text { Aminophospholipid } \\
\text { translocase activity }\end{array}$ & $\begin{array}{l}\text { Decrease with age (defects in } \\
\text { endogenous lipid asymmetry } \\
\text { observed in aged human RBC } \\
\text { may be due to altered activity } \\
\text { of the translocase) }\end{array}$ & [96] \\
\hline LDL from diabetic patients & Fluorimeter & & Increase in diabetes & [72] \\
\hline $\begin{array}{c}\text { Rat liver } \\
\text { aminophospholipids in } \\
\text { streptozotocin-induce } \\
\text { diabetic rats } \\
\end{array}$ & GC-MS & $\begin{array}{l}\text { Amadori } \\
\text { aminophospholipids } \\
\text { (as 5-(hydroxymethyl)-2- } \\
\text { furfuraldehyde; 5-HMF) }\end{array}$ & Increase in diabetes & [73] \\
\hline $\begin{array}{c}\text { RBC and plasma from } \\
\text { diabetic and control } \\
\text { subjects }\end{array}$ & LC-ESI-MS & $\begin{array}{c}\text { Glycated } \\
\text { aminophospholipids }\end{array}$ & Increase in diabetes & [77] \\
\hline $\begin{array}{l}\text { Urine from diabetic and } \\
\text { control subjects }\end{array}$ & GC-MS & $\begin{array}{c}\text { Carboxymethyl- } \\
\text { ethanolamine } \\
\text { (as marker of CM-PE) } \\
\end{array}$ & No increase in diabetes & [54] \\
\hline $\begin{array}{l}\text { Liver mitochondria from } \\
\text { mammalian species }\end{array}$ & GC-MS & $\begin{array}{c}\text { Carboxymethyl- } \\
\text { ethanolamine } \\
\text { (as marker of CM-PE) } \\
\end{array}$ & $\begin{array}{c}\text { CM-PE formation at } \\
\text { mitochondrial level is } \\
\text { associated with animal lifespan }\end{array}$ & [74] \\
\hline $\begin{array}{l}\text { hRBC from diabetic and } \\
\text { control subjects }\end{array}$ & GC-MS & $\begin{array}{c}N \text {-(glucitol)ethanolamine \& } \\
N \text {-(carboxymethyl)serine }\end{array}$ & $\begin{array}{l}\text { Adducts formed in vivo and } \\
\text { increased in diabetes }\end{array}$ & [58] \\
\hline $\begin{array}{l}\text { hLDL from plasma and } \\
\text { atherosclerotic aorta }\end{array}$ & GC-MS & pHA-ethanolamine & $\begin{array}{l}\text { Increase of pHA-PE in human } \\
\text { atherosclerotic intima }\end{array}$ & [59] \\
\hline $\begin{array}{l}\mathrm{RBC} \text { from diabetic and } \\
\text { healthy individuals }\end{array}$ & LC-ESI-MS & $\begin{array}{c}\text { Schiff-PEs, Amadori-PEs, } \\
\text { pyrrole-PE, CM-PE and } \\
\text { CE-PE }\end{array}$ & $\begin{array}{l}\text { Increase in diabetes; glycated } \\
\text { PE promotes lipid peroxidation } \\
\text { of biomembranes }\end{array}$ & [90] \\
\hline $\begin{array}{l}\text { Amadori-PE of a lipid } \\
\text { extract from diabetic } \\
\text { plasma }\end{array}$ & $\begin{array}{l}\text { QTRAP } \\
\text { LC-MS-MS }\end{array}$ & Amadori-PE & Increase in diabetes & {$[105]$} \\
\hline $\begin{array}{l}\text { Plasma from: healthy } \\
\text { volunteers, chronic } \\
\text { hemodyalisis patients, } \\
\text { Type II diabetic patients } \\
\text { without chronic } \\
\text { hemodialysis, and } \\
\text { Type II diabetic patients } \\
\text { with chronic hemodialysis }\end{array}$ & HPLC-MS-MS & Amadori-PE & $\begin{array}{l}\text { Increase of Amadori-PE in } \\
\text { diabetes with or without } \\
\text { chronic hemodialysis }\end{array}$ & [106] \\
\hline $\begin{array}{c}\text { Plasma from } \\
\text { streptozotocin-diabetic } \\
\text { rats }\end{array}$ & LC-ELSD-MS & Amadori-PE & $\begin{array}{l}\text { Increase in diabetes and } \\
\text { decrease in streptozotocin- } \\
\text { induced diabetes and } \\
\text { pyridoxal-treated rats }\end{array}$ & {$[67,68]$} \\
\hline
\end{tabular}


Table 4. Cont.

\begin{tabular}{ccccc}
\hline Experimental model & $\begin{array}{c}\text { Analytical } \\
\text { approach }\end{array}$ & Marker & Finding & Reference \\
\hline $\begin{array}{c}\text { Retinas of streptozotocin- } \\
\text { induced diabetic rats }\end{array}$ & GC-MS & $\begin{array}{c}\text { 4-HHE-, 4-HNE-, and } \\
\text { 4-HDDE-PE }\end{array}$ & Increase in diabetic animals & {$[101]$} \\
\hline $\begin{array}{c}\text { hRBC and blood plasma } \\
\text { from healthy subjects and } \\
\text { diabetic patients }\end{array}$ & LC-MS-MS & CM-PE and CE-PE as & $\begin{array}{c}\text { No significant differences were } \\
\text { observed in AGE-PE in RBC } \\
\text { and plasma, whereas }\end{array}$ & {$[107]$} \\
& AGE-PE, and Amadori-PE & $\begin{array}{c}\text { Amadori-PE concentrations } \\
\text { were higher in diabetic patients }\end{array}$ & \\
\hline $\begin{array}{c}\text { Blood plasma, kidney, } \\
\text { RBCs, liver, pancreas, } \\
\text { cerebrum, and cerebellum } \\
\text { from streptozotocin- } \\
\text { induced diabetes rats }\end{array}$ & LC-MS-MS & Amadori-PE & $\begin{array}{c}\text { Increase in diabetes. } \\
\text { Amadori-PE(18:0-20:4) is the } \\
\text { PE species that acts as the } \\
\text { most sensitive indicator }\end{array}$ & {$[108]$} \\
\hline
\end{tabular}

In another comparative-physiological approach, it was demonstrated that mitochondrial CME levels correlated with lifespan, i.e., levels of CME in short-lived are lower than those of long-lived mammals [74]. In this line, a previous study [109] which evaluated the effects of the aging rate of different mammalian species on the skin collagen concentration of pentosidine, a biomarker of glycoxidative protein damage, showed that although the highest pentosidine accumulation rates were observed in short-lived species, the absolute levels of pentosidine were smaller than those of long-lived species, similarly to the finding of low CME levels in short-lived species. All these data raise the question about the importance of absolute levels of protein and lipid oxidation markers before their accumulation rates. It is conceivable that short-lived species may exhibit higher rates of CME formation, but given the short half-life of aminophospholipids, rates of turnover will presumably be the dominant factor determining the levels of mitochondrial CME. Thus, the observed trends should be ascribed to interespecies differences in CME accumulation and/or phospholipid turnover rates. However, several aspects such as the urinary excretion as the expression of the turnover of damaged aminophospholipids, the implications of CME in mitochondrial and cellular metabolism, and the relationship of CME in mitochondria with the rate of aging remain to be explored.

Diabetes induced a 2.5-fold increase of glycated aminophospholipids in the liver, and $0.025 \% \mathrm{vs}$. $0.01 \%$, in diabetes vs. control [73]. In a LC-MS-based study, it was reported that $1.2 \%$ and $2.3 \%$ of total PE were glycated in human RBC and in plasma lipids, respectively. Furthermore, these values were increased to $10 \%$ and $16 \%$ in diabetic patients, representing a 10 -fold difference [77]. In these studies, special care was taken to not discharge Schiff bases during prechromatographic sample preparation. The Amadori products measurement by GC/MS showed about a three-fold increase in concentrations of GE in RBC lipids from diabetic patients relative to healthy controls [58]. In this line, it was reported that the concentration of phospholipid-MDA crosslink in RBC membranes was elevated approximately three-fold in diabetic subjects [41].

AGE-proteins play a key role as causative agents in the pathogenesis of diabetic complications [110]. In agreement with this concept, concentrations of CML and other AGEs are elevated in different tissues of diabetic patients, correlating with the severity of the chronic 
complications. Since patients that participated in the referred study were free of complications $[58,81]$, the lack of differences in CME levels, as well as CML, between control and patient populations was not an unexpected finding. Furthermore, and consistent with RBC data, neither urine CME nor CML concentrations were significantly increased by diabetes. So, further studies are needed to examine levels of carboxymethylated lipids in diabetic patients with more extensive vascular complications, predicting the existence of differences. In fact, it should be noted that a four-fold increase of MRP-lipids in LDL from diabetic patients $v$ s. healthy subjects was reported by using enzyme-linked immunosorbent assay (ELISA), suggesting a greater increase in Maillard-type modification of aminophospholipids by diabetes [72], although responsible structure/s were not characterized.

In this line, LDL glycation has been suggested to be responsible for the increased susceptibility to atherogenesis of diabetes subjects [111,112]. Thus, a recent report has indicated that PE glycation of LDL is accounted for completely by the known effect of LDL glycation on macrophage uptake, cholesteryl ester and triacylglycerol accumulation. Therefore, there is an increase in LDL atherogenic potential in the diabetic status [79]. Furthermore, and contributing to the pathogenesis of diabetic vascular complications, the interaction of $\mathrm{RBC}$ from diabetic rats with a receptor termed RAGE (receptor for AGEs) has been described [113]. A recent report indicates the recognition of "carboxymethyl" structures by RAGE [114]. This interaction could contribute to the shortened half-life of diabetic RBC when injected into normal animals, leading also to a localized increase in oxidative stress in the vascular wall. The cause of this interaction could be explained by the exposition to the outer layer of the modified aminophospholipids, as previously described. However, the AGE structure(s) on the RBC surfaces mediating their interaction with the RAGE have not been characterized.

\section{Summary}

Membrane composition (phospholipids classes' distribution and fatty acid profile) is strictly and dynamically regulated. The highly unsaturated fatty acids present in cellular membranes are the most susceptible macromolecules to oxidative damage in cells, and this sensitivity increases as a function of the number of their double bonds. Carbonyl-amine reaction-derived molecular damage is a natural consequence of aerobic life. Current data indicate the extension of carbonyl-amine reactions to aminophospholipids. Despite the fact that non-enzymatic modification of aminophospholipids by glycation, carboxymethylation and lipid peroxidation has been described, they represent only a limited range of the possible products that can likely be formed by the Maillard reaction. Due to their important role in cellular homeostasis, further studies are needed to elucidate the potential implications of these reactions on basic life processes.

\section{Acknowledgments}

The authors are grateful to the anonymous reviewers for their criticisms and suggestions, which improved the manuscript. Work carried out at the Department of Experimental Medicine was supported in part by $\mathrm{R}+\mathrm{D}$ grants from the Spanish Ministry of Science and Innovation, and the Autonomous Government of Catalonia. The authors declare no conflict of interest. 


\section{References}

1. Yeagle, P. The Membranes of Cells; Academic Press: San Diego, CA, USA, 1993; pp. 1-349.

2. Vance, D.E.; Vance, J.E. Biochemistry of Lipids, Lipoproteins and Membranes; Elsevier Science BV: Amsterdam, The Netherlands, 1996; pp. 1-553.

3. Vereb, G.; Szollosi, J.; Matko, J.; Nagy, P.; Farkas, T.; Vigh, L.; Matyus, L.; Waldmann, T.A.; Damjanovich, S. Dynamic, yet structured: The cell membrane three decades after the Singer-Nicolson model. Proc. Natl. Acad. Sci. USA 2003, 100, 8053-8058.

4. Ikeda, M.; Kihara, A.; Igarashi, Y. Lipid asymmetry of the eukaryotic plasma membrana: Functions and related enzymes. Biol. Pharm. Bull. 2006, 29, 1542-1546.

5. Lenoir, G; Williamson, P.; Holthuis, J.C.M. On the origin of lipid asymmetry: The flip side of ion transport. Curr. Opin. Chem. Biol. 2007, 11, 654-661.

6. Dowhan, W. Molecular basis for membrane phospholipid diversity: Why are there so many lipids? Ann. Rev. Biochem. 1997, 66, 199-232.

7. Van Meer, G. Cellular lipidomics. EMBO J. 2005, 24, 3159-3165.

8. Portero-Otín, M.; Bellmunt, M.J.; Ruiz, M.C.; Barja, G.; Pamplona, R. Correlation of fatty acid unsaturation of the major liver mitochondrial phospholipid classes in mammals to their maximum life span potential. Lipids 2001, 36, 491-498.

9. Van Meer, G.; Voelker, D.R.; Feigenson, G.W. Membrane lipids: Where they are and how they behave. Nat. Rev. Mol. Cell Biol. 2008, 9, 112-124.

10. Hermansson, M.; Hokynar, K.; Somerharju, P. Mechanisms of glycerophospholipid homeostasis in mammalian cells. Prog. Lipid Res. 2011, 50, 240-257.

11. Schroit, A.J.; Zwaal, R.F.A. Transbilayer movement of phospholipids in red cell and platelet membranes. Biochim. Biophys. Acta 1991, 1071, 313-329.

12. Balasubramanian, K.; Schroit, A.J. Aminophospholipid asymmetry: A matter of lifeand death. Ann. Rev. Physiol. 2003, 65, 701-734.

13. Wallis, J.G.; Watts, J.L.; Browse, J. Polyunsaturated fatty acid synthesis: What will they think of next? Trends Biochem. Sci. 2002, 27, 467-473.

14. Pamplona, R. Membrane phospholipids, lipoxidative damage and molecular integrity: A causal role in aging and longevity. Biochim. Biophys. Acta 2008, 1777, 1249-1262.

15. Hulbert, A.J.; Pamplona, R.; Buffenstein, R.; Buttemer, W.A. Life and death: Metabolic rate, membrane composition, and life span of animals. Physiol. Rev. 2007, 87, 1175-1213.

16. Moller, M.; Botti, H.; Batthyany, C.; Rubbo, H.; Radi, R.; Denicola, A. Direct measurement of nitric oxide and oxygen partitioning into liposomes and low density lipoprotein. J. Biol. Chem. 2005, 280, 8850-8854.

17. Gamliel, A.; Afri, M.; Frimer, A.A. Determining radical penetration of lipid bilayers with new lipophilic spin traps. Free Radical Biol. Med. 2008, 44, 1394-1405.

18. Holman, R.T. Autoxidation of Fats and Related Substances. In Progress in Chemistry of Fats and Other Lipids; Holman, R.T., Lundberg, W.O., Malkin, T., Eds.; Pergamon Press: London, UK, 1954; pp. 51-98.

19. Bielski, B.H.; Arudi, R.L.; Sutherland, M.W. A study of the reactivity of $\mathrm{HO}_{2} / \mathrm{O}_{2}{ }^{-}$with unsaturated fatty acids. J. Biol. Chem. 1983, 258, 4759-4761. 
20. Esterbauer, H.; Schaur, R.J.; Zollner, H. Chemistry and biochemistry of 4-hydroxynonenal, malonaldehyde and related aldehydes. Free Radical Biol. Med. 1991, 11, 81-128.

21. Aldini, G.; Dalle-Donne, I.; Facino, R.M.; Milzani, A.; Carini, M. Intervention strategies to inhibit protein carbonylation by lipoxidation-derived reactive carbonyls. Med. Res. Rev. 2007, 27, 817-868.

22. Thorpe, S.R.; Baynes, J.W. Maillard reaction products in tissue proteins: New products and new perspectives. Amino Acids 2003, 25, 275-281.

23. Pamplona, R. Advanced lipoxidation end-products. Chem.-Biol. Interact. 2011, 192, 14-20.

24. Terman, A.; Brunk, U.T. Lipofuscin. Int. J. Biochem. Cell Biol. 2004, 36, 1400-1404.

25. West, J.D.; Marnett, L.J. Endogenous reactive intermediates as modulators of cell signalling and cell death. Chem. Res. Toxicol. 2006, 19, 173-194.

26. Baynes, J.W.; Monnier, V.M. The Maillard Reaction in Aging, Diabetes and Nutrition; Liss: New York, NY, USA, 1989.

27. Portero-Otin, M.; Pamplona, R. Is Endogenous Oxidative Protein Damage Envolved in the Aging Process? In Protein Oxidation and Disease; Pietzsch, J., Ed.; Research Signpost: Kerala, India, 2006; pp. 91-142.

28. Baynes, J.W. The Role of Oxidation in the Maillard Reaction in vivo. In The Maillard Reaction: Consequences for the Chemical and Life Sciences; Ika, R., Ed.; John Wiley \& Sons: Chichester, UK, 1996; pp. 55-72.

29. Corliss, G.A.; Dugan, L.R. Phospholipid oxidation in emulsions. Lipids 1970, 5, 846-853.

30. Popjak, G.; LeBreton, E. Biochemical Problems of Lipids; Interscience Publishers Inc.: New York, NY, USA, 1956; p. 81.

31. Dillard, C.J.; Tappel, A.L. Fluorescent products from reaction of peroxidizing polyunsaturated fatty acids with phosphatidyl ethanolamine and phenylalanine. Lipids 1973, 8, 183-189.

32. Bidlack, W.R.; Tappel, A.L. Fluorescent products of phospholipids during lipid peroxidation. Lipids 1973, 8, 203-207.

33. Shimasaki, H.; Ueta, N.; Mowri, H.-O.; Inoue, K. Formation of age pigment-like fluorescent substances during peroxidation of lipids in model membranes. Biochim. Biophys. Acta 1984, 792, $123-129$.

34. Tsuchida, M.; Miura, T.; Aibara, K. Lipofucsin and lipofucsin-like substances. Chem. Phys. Lipids 1987, 44, 297-325.

35. Jain, S.K.; Hochstein, P. Polymerization of membrane components in aging red blood cells. Biochem. Biophys. Res. Commun. 1980, 92, 247-254.

36. Jain, S.K.; Yip, R.; Hoesch, R.M.; Pramanik, A.K.; Dallman, P.R.; Shohet, S.B. Evidence of peroxidative damage to the erythrocyte membrane in iron deficiency. Am. J. Clin. Nutr. 1983, 37, 26-30.

37. Jain, S.K.; Shohet, S.B. A novel phospholipid in irreversibly sickled cells: Evidence for in vivo peroxidative membrane damage in sickle cell disease. Blood 1984, 63, 362-367.

38. Jain, S.K. The accumulation of malonyldialdehyde, a product of fatty acid peroxidation, can disturb aminophospholipid organization in the membrane bilayer of human erythrocytes. J. Biol. Chem. 1984, 259, 3391-3394. 
39. Jain, S.K. In vivo externalization of phosphatidylserine and phosphatidylethanolamine in the membrane bilayer and hypercoagulability by the lipid peroxidation of erythrocytes in rats. J. Clin. Invest. 1985, 76, 281-286.

40. Jain, S.K. Evidence for membrane lipid peroxidation during the in vivo aging of human erythrocytes. Biochim. Biophys. Acta 1988, 937, 205-210.

41. Jain, S.K.; McVie, R.; Duett, J.; Herbst, J.J. Erythrocyte membrane lipid peroxidation and glycosylated hemoglobin in diabetes. Diabetes 1989, 38, 1539-1543.

42. Jain, S.K. Hyperglycemia can cause membrane lipid peroxidation and osmotic fragility in human red blood cells. J. Biol. Chem. 1989, 264, 21340-21345.

43. Bhuyan, K.C.; Master, R.W.; Coles, R.S.; Bhuyan, D.K. Molecular mechanisms of cataractogenesis: IV. Evidence of phospholipid.malondialdehyde adduct in human senile cataract. Mech. Ageing Dev. 1986, 34, 289-296.

44. Bhuyan, D.K.; Master, R.W.; Bhuyan, K.C. Crosslinking of aminophospholipids in cellular membranes of lens by oxidative stress in vitro. Biochim. Biophys. Acta 1996, 1285, 21-28.

45. Esterbauer, H.; Koller, E.; Slee, R.G.; Koster, J.F. Possible involvement of the lipid-peroxidation product 4-hydroxynonenal in the formation of fluorescent chromolipids. Biochem. J. 1986, 239, 405-409.

46. Guichardant, M.; Taibi-Tronche, P.; Fay, L.B.; Lagarde, M. Covalent modifications of aminophospholipids by 4-hydroxynonenal. Free Radic. Biol. Med. 1998, 25, 1049-1056.

47. Dillard, C.J.; Tappel, A.L. Fluorescent products of lipid peroxidation of mitochondria and microsomes. Lipids 1971, 6, 715-721.

48. Koster, J.F.; Slee, R.G. Lipid peroxidation of rat liver microsomes. Biochim. Biophys. Acta 1980, 620, 489-499.

49. Kikugawa, K.; Ido, Y. Studies on peroxidized lipids. V. Formation and characterization of 1,4-dihydropyridine-3,5-dicarbaldehydes as model of fluorescent components in lipofuscin. Lipids 1984, 19, 600-608.

50. Hadley, M.; Draper, H.H. Identification of $N$-(2-propenal)serine as a urinary metabolite of malondialdehyde. FASEB J. 1988, 2, 138-140.

51. Hadley, M.; Draper, H.H. Identification of $N$-(2-propenal)ethanolamine as a urinary metabolite of malondialdehyde. Free Radical Biol. Med. 1989, 6, 49-52.

52. Wang, J.-Y.; Wang, Z.-Y.; Kouyama, T.; Shibata, T.; Ueki, T. Significance of amino groups of phosphatidylethanolamine in phospholipid peroxidation of mixed liposomes. Chem. Phys. Lipids 1994, 71, 197-203.

53. Ravandi, A.; Kuksis, A.; Marai, L.; Myher, J.J. Preparation and characterization of glucosylated aminoglycerophospholipids. Lipids 1995, 30, 885-891.

54. Requena, J.R.; Ahmed, M.U.; Fountain, C.W.; Degenhardt, T.P.; Reddy, S.; Perez, C.; Lyons, T.J.; Jenkins, A.J.; Baynes, J.W.; Thorpe, S.R. Carboxymethylethanolamine, a biomarker of phospholipid modification during the Maillard reaction in vivo. J. Biol. Chem. 1997, 272, 17473-17479.

55. Lederer, M.O.; Dreisbusch, C.M.; Bundschuh, R.M. Amadori products from model reactions of D-glucose with phosphatidyl ethanolamine. Independent synthesis and identification of 1-deoxy-1-(2-hydroxyethylamino)-D-fructose derivatives. Carbohyd. Res. 1997, 301, 111-121. 
56. Lertsiri, S.; Shiraishi, M.; Miyazawa, T. Identification of deoxy-D-fructosyl phosphatidyl ethanolamine as a non-enzymic glycation product of phosphatidyl ethanolamine and its occurrence in human blood plasma and red blood cells. Biosci. Biotechnol. Biochem. 1998, 62, 893-901.

57. Argirov, O.K.; Kerina, I.I.; Uzunova, J.I.; Argirova, M.D. Modeling of Protein and Aminophospholipid Glycation Using Low Molecular Weight Analogs. A Comparative Study. In The Maillard Reaction in Foods and Medicine; O'brien, J., Nursten, H.E., Crabbe, M.J.C., Ames, J.M., Eds.; The Royal Society of Chemistry: Cambridge, UK, 1998; pp. 245-249.

58. Fountain, W.C.; Requena, J.R.; Jenkins, A.J.; Lyons, T.J.; Smyth, B.; Baynes, J.W.; Thorpe, S.R. Quantification of $N$-(Glucitol)ethanolamine and $N$-(Carboxymethyl)serine: Two products of nonenzymatic modification of aminophospholipids formed in vivo. Anal. Biochem. 1999, 272, 48-55.

59. Heller, J.I.; Crowley, J.R.; Hazen, S.L.; Salvay, D.M.; Wagner, P.; Pennathur, S.; Heinecke, J.W. p-Hydroxyphenylacetaldehyde, an aldehyde generated by myeloperoxidase, modififes phospholipid amino groups of low density lipoprotein in human atherosclerotic intima. J. Biol. Chem. 2000, 275, 9957-9962.

60. Lederer, M.O.; Baumann, M. Formation of a phospholipid-linked pyrrolecarbaldehyde from model reactions of D-glucose and 3-deoxyglucosone with phosphatidyl ethanolamine. Bioorgan. Med. Chem. 2000, 8, 115-121.

61. Utzmann, C.M.; Lederer, M.O. Independent synthesis of aminophospholipid-linked Maillard products. Carbohyd. Res. 2000, 325, 157-168.

62. Zamora, R.; Hidalgo, F.J. Phosphatidylethanolamine modification by oxidative stress product 4,5(E)-epoxy-2(E)-heptenal. Chem. Res. Toxicol. 2003, 16, 1632-1641.

63. Tsuji, K.; Kawai, Y.; Kato, Y.; Osawa, T. Formation of $N$-(hexanoyl)ethanolamine, a novel phosphatidylethanolamine adduct, during the oxidation of erythrocyte membrane and low-density lipoprotein. Biochem. Biophys. Res. Commun. 2003, 306, 706-711.

64. Bacot, S.; Bernoud-Hubac, N.; Baddas, N.; Chantegrel, B.; Deshayes, C.; Doutheau, A.; Lagarde, M.; Guichardant, M. Covalent binding of hydroxyl-alkenals 4-HDDE, 4-HHE, and 4-HNE to ethanolamine phospholipid subclasses. J. Lipid Res. 2003, 44, 917-926.

65. Bernoud-Hubac, N.; Fay, L.B.; Armarnath, V.; Guichardant, M.; Bacot, S.; Davies, S.S.; Jackson Roberts, L., II; Lagarde, M. Covalent binding of isoketals to ethanolamine phospholipids. Free Radical Biol. Med. 2004, 37, 1604-1611.

66. Stadelmann-Ingrand, S.; Pontcharraud, R.; Fauconneau, B. Evidence for the reactivity of fatty aldehydes released from oxidized plasmalogens with phosphatidylethanolamine to form Schiff base adducts in rat brain homogenates. Chem. Phys. Lipids 2004, 131, 93-105.

67. Higuchi, O.; Nakagawa, K.; Tsuzuki, T.; Suzuki, T.; Oikawa, S.; Miyazawa, T. Aminophospholipid glycation and its inhibitor screening system: A new role of pyridoxal 5'-phosphate as the inhibitor. J. Lipid Res. 2006, 47, 964-974.

68. Miyazawa, T.; Ibusuki, D.; Yamashita, S.; Nakagawa, K. Analysis of amadori-glycated phosphatidylethanolamine in the plasma of healthy subjects and diabetic patients by liquid chromatography-tandem mass spectrometry. Ann. N. Y. Acad. Sci. 2008, 1126, 291-294. 
69. Aguilar-Hernandez, M.; Mendez, J.D. In vitro glycation of brain aminophospholipids by acetoacetate and its inhibition by urea. Biomed. Pharmacother. 2007, 61, 693-697.

70. Solis-Calero, C.; Ortega-Castro, J.; Muñoz, F. Reactivity of a phospholipid monolayer model under periodic boundary conditions: A density functional theory study of the Schiff base formation between phosphatidylethanolamine and acetaldehyde. J. Phys. Chem. 2010, 114, 15879-15885.

71. Guo, L.; Chen, Z.; Amarnath, V.; Davies, S.S. identification of novel bioactive aldehyde-modified phosphatidylethanolamines formed by lipid peroxidation. Free Radic. Biol. Med. 2012, 53, 1226-1238.

72. Bucala, R.; Makita, Z.; Koschinsky, T.; Cerami, A.; Vlassara, H. Lipid advanced glycosylation: Pathway for lipid oxidation in vivo. Proc. Natl. Acad. Sci. USA 1993, 90, 6434-6438.

73. Pamplona, R.; Bellmunt, M. J.; Portero-Otin, M.; Riba, D.; Prat, J. Chromatographic evidence for Amadori product formation in rat liver aminophospholipids. Life Sci. 1995, 57, 873-879.

74. Pamplona, R.; Requena, J.R.; Portero-Otin, M.; Prat, J.; Thorpe, S.R.; Bellmunt, M.J. Carboxymethylated phosphatidylethanolamine in mitochondrial membranes of mammals. Evidence for intracellular lipid glycoxidation. Eur. J. Biochem. 1998, 225, 685-689.

75. Requena, J.R.; Ahmed, M.U.; Reddy, S.; Fountain, C.W.; Degenhardt, T.P.; Jenkins, A.J.; Smyth, B.; Lyons, T.J.; Thorpe, S.R. Detection of AGE-Lipids in vivo: Glycation and Carboxymethylation of Aminophospholipids in Red Cell Membranes. In The Maillard Reaction in Foods and Medicine; O’brien, J., Nursten, H.E., Crabbe, M.J.C., Ames, J.M., Eds.; The Royal Society of Chemistry: Cambridge, UK, 1998; pp. 363-368.

76. Oak, J.-H.; Nakagawa, K.; Miyazawa, T. UV analysis of Amadori-glycated phosphatidylethanolamine in foods and biological samples. J. Lipid Res. 2002, 43, 523-529.

77. Ravandi, A.; Kuksis, A.; Marai, L.; Myher, J.J.; Steiner, G.; Lewisa, G.; Kamido, H. Isolation and identification of glycated aminophospholipids from red cells and plasma of diabetic blood. FEBS Lett. 1996, 381, 77-81.

78. Ravandi, A.; Kuksis, A.; Shaikh, N.; Jackowski, G. Preparation of Schiff base adducts of phosphatidylcholine core aldehydes and aminophospholipids, amino acids, and myoglobin. Lipids 1997, 32, 989-1001.

79. Ravandi, A.; Kuksis, A.; Shaikh, N.A. Glycated phosphatidylethanolamine promotes macrophage uptake of low density lipoprotein and accumulation of cholesteryl esters and triacylglycerols. J. Biol. Chem. 1999, 274, 16494-16500.

80. Reddy, S.; Bichler, J.; Wells-Knecht, K.J.; Thorpe, S.R.; Baynes, J.W. $\mathrm{Ne}$-(Carboxymethyl)lysine is a dominant advanced glycation end product (AGE) antigen in tissue proteins. Biochemistry 1995, 34, 10872-10878.

81. Jenkins, A.; Lyons, T.J.; Smyth, B.; Requena, J.R.; Fountain, C.W.; Hermayer, K.L.; Phillips, K.D.; King, L.P.; Baynes, J.W.; Thorpe, S.R. Glycoxidation and lipoxidation products in red blood cell membranes in IDDM. Relationship to glycemic control and microvascular complications. Diabetes 1998, 47, A127.

82. Fu, M.X.; Requena, J.R.; Jenkins, A.J.; Lyons, T.J.; Baynes, J.W.; Thorpe, S.R. The advanced glycation end product Ne-(Carboxymethyl)lysine is a product of both lipid peroxidation and glycoxidation reactions. J. Biol. Chem. 1996, 271, 9982-9986. 
83. Anderson, M.M.; Requena, J.R.; Crowley, J.R.; Thorpe, S.R.; Heinecke, J.W. The myeloperoxidase system of human phagocytes generates $\mathrm{Ne}$-(carboxymethyl)lysine on proteins: A mechanism for producing advanced glycation end products at sites of inflammation. J. Clin. Invest. 1999, 104, 103-113.

84. Prat, J., Bellmunt, M.J., Portero-Otín, M., Pamplona, R. Fluorescent Products from Aminophospholipids and Glucose. In The Maillard Reaction in Foods and Medicine; O'brien, J., Nursten, H.E., Crabbe, M.J.C., Ames, J.M., Eds.; The Royal Society of Chemistry: Cambridge, UK, 1998; p. 438.

85. Al-Abed, Y.; Liebich, H.; Voelter, W.; Bucala, R. Hydroxyalkenal formation induced by advanced glycosylation of low density lipoprotein. J. Biol. Chem. 1996, 271, 2892-2896.

86. Obsil, T.; Amler, E.; Obsilova, V.; Pavlicek, Z. Effect of aminophospholipid glycation on order parameter and hydration of phospholipid bilayer. Biophys. Chem. 1999, 80, 165-177.

87. Ravandi, A.; Kuksis, A.; Shaikh, N.A. Glucosylated glycerophosphoethanolamines are the major LDL glycation products and increase LDL susceptibility to oxidation. Arterioscl. Throm. Vas. Biol. 2000, 20, 467-477.

88. Utzmann, C.M.; Lederer, M.O. Identification and quantification of aminophospholipid-linked Maillard compounds in model systems and egg yolk products. J. Agric. Food Chem. 2000, 48, 1000-1008.

89. Oak, J.-H.; Nakagawa, K.; Miyazawa, T. Synthetically prepared Amadori-glycated phosphatidylethanolamine can trigger lipid peroxidation via free radical reactions. FEBS Lett. 2000, 481, 26-30.

90. Breitling-Utzmann, C.M.; Unger, A.; Friedl, D.A.; Lederer, M.O. Identification and quantification of phosphatidylethanolamine-derived glucosylamines and aminoketoses from human erythrocytes-Influence of glycation products on lipid peroxidation. Archives Biochem. Biophys. 2001, 391, 245-254.

91. Lecompte, M-F.; Clavilier, J.; Rolland, C.; Collet, X.; Negre-Salvayre, A.; Salvayre, R. Effect of 4-hydroxynonenal on phosphatidylethanolamine containing condensed monolayer and on its interaction with apolipoprotein A-I. FEBS Lett. 2005, 579, 5074-5078.

92. Levi, V.; Villamil Giraldo, A.M.; Castello, P.R.; Rossi, J.P.F.C.; Gonzalez Flecha, F.L. Effects of phosphatidylethanolamine glycation on lipid-protein interactions and membrane protein thermal stability. Biochem. J. 2008, 416, 145-152.

93. Simoes, C.; Simoes, V.; Reis, A.; Domingues, P.; Domingues, M.R.M. Oxidation of glycated phosphatidylethanolamines: Evidence of oxidation in glycated polar head identified by LC-MS/MS. Anal. Bioanal. Chem. 2010, 397, 2417-2427.

94. Simoes, C.; Domingues, P.; Domingues, M.R.M. Identification of free radicals in oxidized and glycoxidized phosphatidylethanolamines by spin trapping combined with tandem mass spectrometry. Rapid Commun. Mass Spectrom. 2012, 26, 931-939.

95. Herrmann, A.; Devaux, P.F. Alteration of the aminophospholipid translocase activity during in vivo and artificial aging of human erythrocytes. Biochim. Biophys. Acta1990, 1027, 41-46.

96. Zieseniss, S.; Zahler, S.; Müller, I.; Hermetter, A.; Engelmann, B. Modified phosphatidylethanolamine as the active component of oxidized low density lipoprotein promoting platelet prothrombinase activity. J. Biol. Chem. 2001, 276, 19828-19835. 
97. Guichardant, M.; Bernoud-Hubac, N.; Chantegrel, B.; Deshayes, C.; Lagarde, M. Aldehydes from n-6 fatty acid peroxidation. Effects on aminophospholipids. Protag. Leukotr. Ess. Fatty Acids 2002, 67, 147-149.

98. Oak, J.-H.; Nakagawa, K.; Oikawa, S.; Miyazawa, T. Amadori-glycated phosphatidylethanolamine induces angiogenic differentiations in cultured human umbilical vein endothelial cells. FEBS Lett. 2003, 555, 419-423.

99. Nakagawa, K.; Oak, J.-H.; Miyazawa, T. Angiogenic potency of Amadori-glycated phosphatidylethanolamine. Ann. N. Y. Acad. Sci. 2005, 1043, 413-416.

100. Bacot, S.; Bernoud-Hubac, N.; Chantegrel, B.; Deshayes, C.; Doutheau, A.; Ponsin, G.; Lagarde, M.; Guichardant, M. Evidence for in situ ethanolamine phospholipid adducts with hydroxyl-alkenals. J. Lipid Res. 2007, 48, 816-825.

101. Fadok, V.A.; Bratton, D.L.; Frasch, S.C.; Warner, M.L.; Henson, P.M. The role of phosphatidylserine in recognition of apoptotic cells by phagocytes. Cell Death Differ. 1998, 5, 551-562.

102. Brenner, R.R. Effect of unsaturated acids on membrane structure and enzyme kinetics. Prog. Lipid Res. 1984, 23, 69-96.

103. Daum, G. Lipids of mitochondria. Biochim. Biophys. Acta 1985, 822, 1-42.

104. Tyler, D. The Mitochondrion in Health and Disease; VCH Publishers: New York, NY, USA, 1992; pp. 78-80.

105. Nakagawa, K.; Oak, J-H.; Higuchi, O.; Tsuzuki, T.; Oikawa, S.; Otani, H.; Mune, M.; Cai, H.; Miyazawa, T. Ion-trap tándem mass spectrometric analysis of Amadori-glycated phosphatidylethanolamine in human plasma with or without diabetes. J. Lipid Res. 2005, 46, 2514-2524.

106. Miyazawa, T.; Oak, J.-H.; Nakagawa, K. tándem mass spectrometry analysis of Amadori-glycated phosphatidylethanolamine in human plasma. Ann. N. Y. Acad. Sci. 2005, 1043, 280-283.

107. Shoji, N.; Nakagawa, K.; Asai, A.; Fujita, I.; Hashiura, A.; Nakajima, Y.; Oikawa, S.; Miyazawa, T. LC-MS/MS analysis of carboxymethylated and carboxyethylated phosphatidylethanolamines in human erythrocytes and blood plasma. J. Lipid Res. 2010, 51, 2445-2453.

108. Sookwong, P.; Nakagawa, K.; Fujita, I.; Shoji, N.; Miyazawa, T. Amadori-glycated phosphatidylethanolamine, a potential marker for hyperglycemia, in streptozotocin-induced diabetic rats. Lipids 2011, 46, 943-952.

109. Sell, D.R.; Lane, M.A.; Johnson, W.A.; Masoro, E.J.; Mock, O.B.; Reiser, K.M.; Fogarty, J.F.; Cutler, R.G.; Ingram, D.K.; Roth, G.S.; et al. Longevity and the genetic determination of collagen glycoxidation kinetics in mammalian senescence. Proc. Natl. Acad. Sci. USA 1996, 93, 485-490.

110. Baynes, J.W.; Thorpe, S.R. Role of oxidative stress in diabetic complications. A new perspective on an old paradigm. Diabetes 1999, 48, 1-9.

111. Prat, J.; Pamplona, R.; Sorribas, A.; Martín, S.; Viñallonga, M.; Segura, R. Correlation of plasma lipid fractions with colorimetrically determined glycated hemoglobin in a nondiabetic population. Metabolism 1989, 38, 1147-1153. 
112. Pamplona, R.; Belmunt, M.J.; Portero-Otín, M.; Prat, J. Mechanisms of glycation in atherogenesis. Med. Hypotheses 1993, 40, 174-181.

113. Wautier, J.L.; Wautier, M.P.; Schmidt, A.M.; Anderson, G.M.; Hori, O.; Zoukourian, C.; Capron, L.; Chappey, O.; Yan, S.D.; Brett, J.; et al. Advanced glycation end products (AGEs) on the surface of diabetic erythrocytes bind to the vessel wall via a specific receptor inducing oxidant stress in the vasculature: A link between surface-associated AGEs and diabetic complications. Proc. Natl. Acad. Sci. USA 1994, 91, 7742-7746.

114. Kislinger, T.; Fu, C.; Huber, B.; Qu, W.; Taguchi, A.; Du Yan, S.; Hofmann, M.; Yan, S.F.; Pischetsrieder, M.; Stern, D.; et al. N(epsilon)-(carboxymethyl)lysine adducts of proeins are ligands for receptor for advanced glycation end products that activate cell signaling pathways and modulate gene expression. J. Biol. Chem. 1999, 274, 31740-31749.

(C) 2013 by the authors; licensee MDPI, Basel, Switzerland. This article is an open access article distributed under the terms and conditions of the Creative Commons Attribution license (http://creativecommons.org/licenses/by/3.0/). 